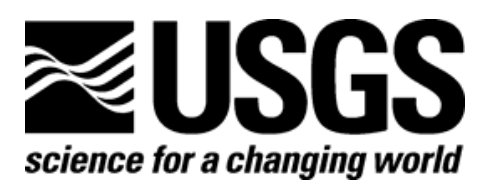

\title{
Surficial Sediment Character of the Louisiana Offshore Continental Shelf Region: a GIS Compilation
}

By S. Jeffress Williams ', Matthew A. Arsenault', Brian J. Buczkowski', Jane A. Reid', James Flocks ${ }^{3}$, Mark A. Kulp ${ }^{4}$, Shea Penland ${ }^{4}$ and Chris J. Jenkins ${ }^{5}$

${ }^{1}$ U.S. Geological Survey, Woods Hole Science Center, 384 Woods Hole Rd. Woods Hole, MA 02543

${ }^{2}$ U.S. Geological Survey, Western Coastal and Marine Geology, Pacific Science Center, 400 Natural Bridges Drive, Santa Cruz, CA 95060

${ }^{3}$ U.S. Geological Survey, 600 4th Street South, St. Petersburg, FL 33701

${ }^{4}$ Department of Geology and Geophysics, University of New Orleans, New Orleans, LA 70148

${ }^{5}$ Institute of Arctic and Alpine Research, University of Colorado at Boulder, 1560 30th Street, Campus Box 450, Boulder, CO 80309-0450

U.S. Geological Survey Open-File Report 2006-1195

U.S. Department of the Interior

U.S. Geological Survey 


\section{U.S. Department of the Interior \\ Dirk Kempthorne, Secretary}

\section{U.S. Geological Survey \\ Mike D. Myers, Director}

\section{U.S. Geological Survey, Reston, Virginia 2007}

For product and ordering information:

World Wide Web: http://www.usgs.gov/pubprod

Telephone: 1-888-ASK-USGS

For more information on the USGS - the Federal source for science about the Earth, its natural and living resources, natural hazards, and the environment:

World Wide Web: http://www.usgs.gov

Telephone: 1-888-ASK-USGS

Suggested citation:

CITATION: This document should be cited as: Williams, S.J., Arsenault, M.A., Buczkowski, B.J., Reid, J.A., Flocks, J., Kulp, M.A., Penland, S., and Jenkins, C.J., 2006, Surficial sediment character of the Louisiana offshore Continental Shelf region: a GIS Compilation, U.S. Geological Survey Open-File Report 2006-1195, online at http://pubs.usgs.gov/of/2006/1195/index.htm.

Any use of trade, product, or firm names is for descriptive purposes only and does not imply endorsement by the U.S. Government.

Although this report is in the public domain, permission must be secured from the individual copyright owners to reproduce any copyrighted material contained within this report. 


\section{Contents}

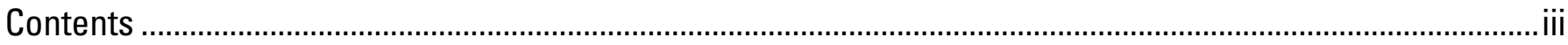

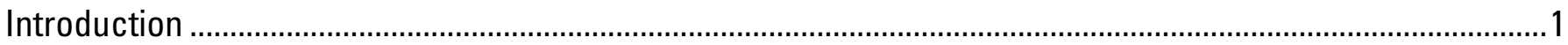

Setting

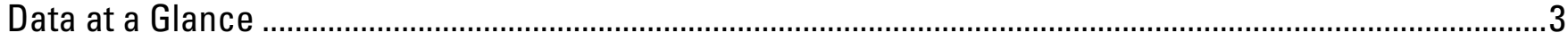

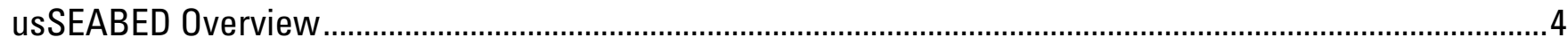

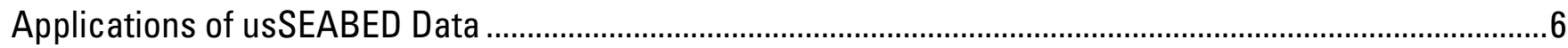

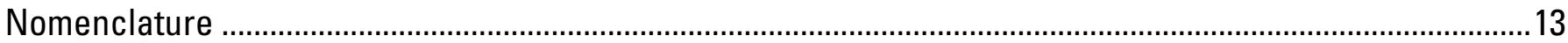

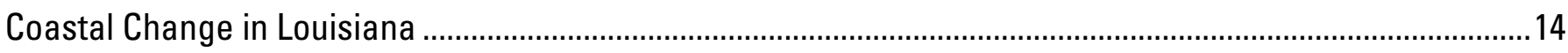

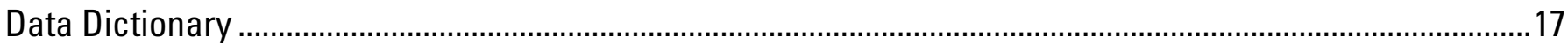

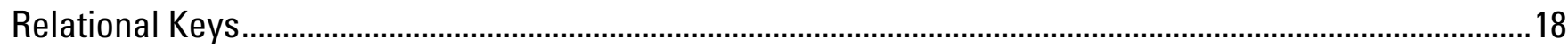

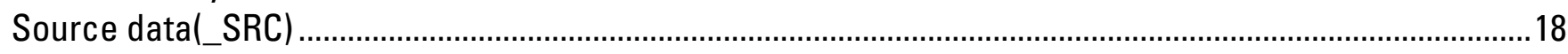

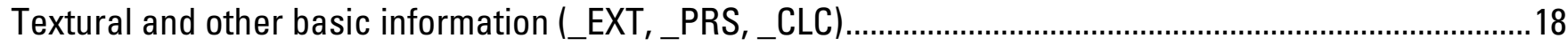

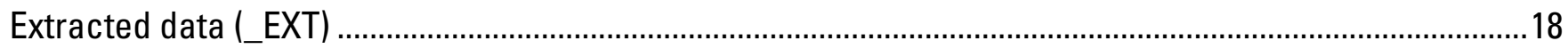

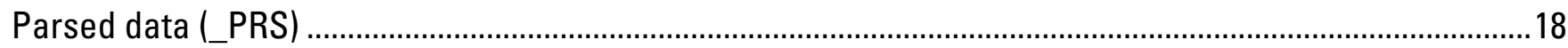

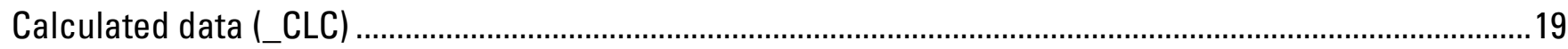

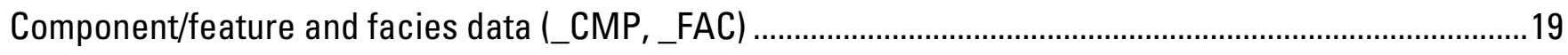

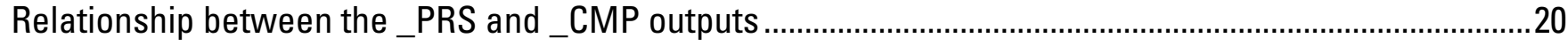

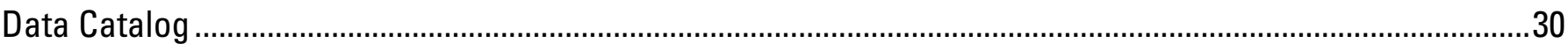

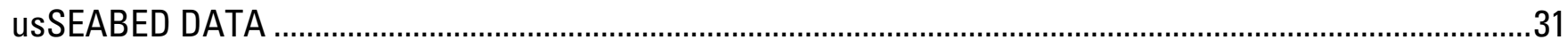

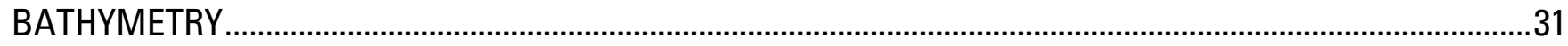

BASEMAPS .

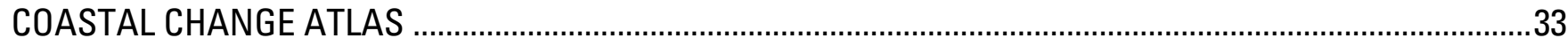

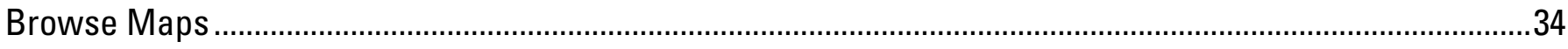

Overview.

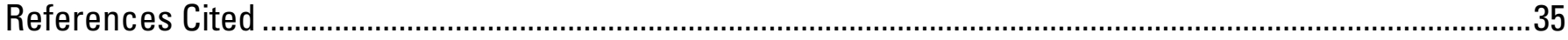

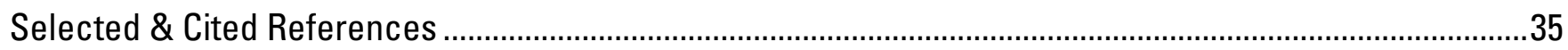

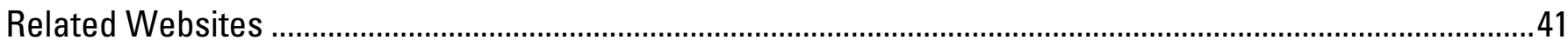

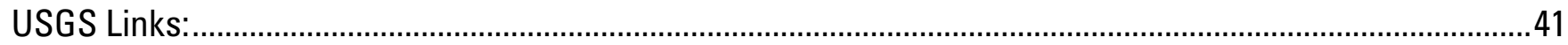

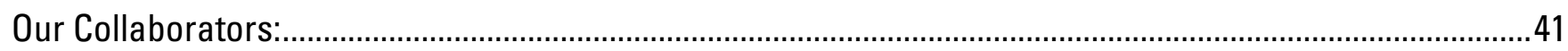

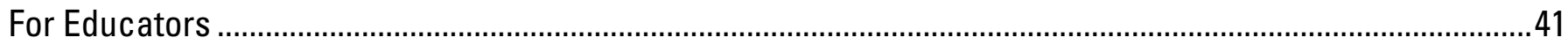

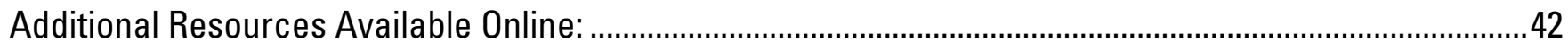

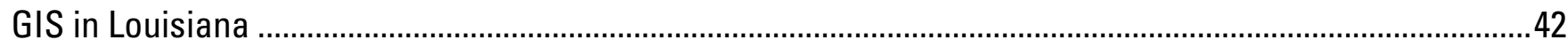

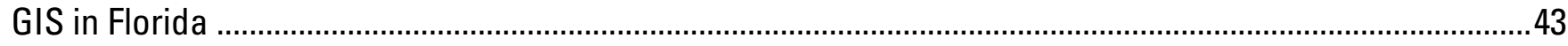

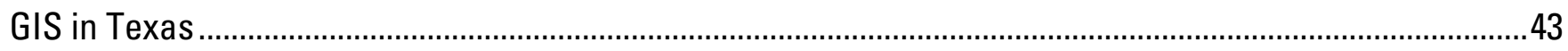

GIS in Alabama

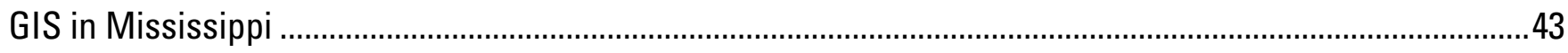

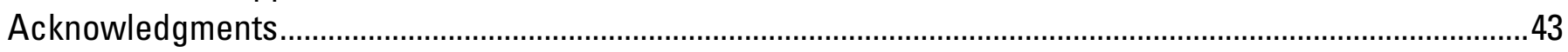

Contacts

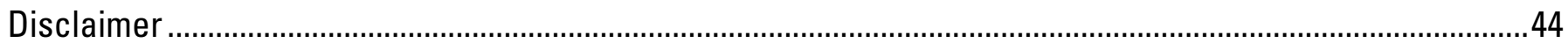

General

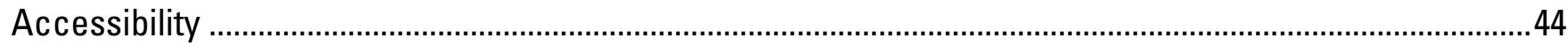

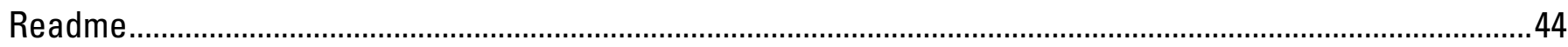




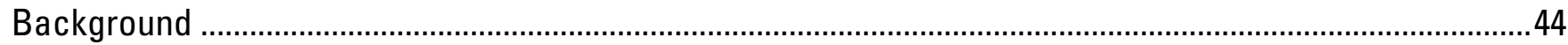




\title{
Surficial Sediment Character of the Louisiana Offshore Continental Shelf Region: a GIS Compilation
}

\author{
By S. Jeffress Williams, Matthew A. Arsenault, Brian J. Buczkowski, Jane A. Reid, James Flocks, \\ Mark A. Kulp, Shea Penland, and Chris J. Jenkins
}

\section{Introduction}

\section{Setting}

The Louisiana coastal zone, comprising the Mississippi River delta plain stretching nearly $400 \mathrm{~km}$ from Sabine Pass at the Texas border east to the Chandeleur Islands at the Mississippi border, represents one of North America's most important coastal ecosystems in terms of natural resources, human infrastructure, and cultural heritage. At the same time, this region has the highest rates of coastal erosion and wetland loss in the Nation due to a complex combination of natural processes and anthropogenic actions over the past century. Comparison of historical maps dating back to 1855 and recent aerial photography show the Louisiana coast undergoing net erosion at highly variable rates. Rates have increased significantly during the past several decades. Earlier published statewide average shoreline erosion rates were $>6 \mathrm{~m} / \mathrm{yr}$; rates have increased recently to $>10 \mathrm{~m} / \mathrm{yr}$. The increase is attributable to collective action of storms, rapid subsidence, and pervasive man-made alterations of the rivers and the coast. In response to the dramatic landloss, regional-scale restoration plans are being developed by a partnership of federal and state agencies for the delta plain that have the objectives of maintaining the barrier islands, reducing wetland loss, and enhancing the natural sediment delivery processes.

There is growing awareness that the sustainability of coastal Louisiana's natural resources and human infrastructure depends on the successful restoration of natural geologic processes. Critical to the long term success of restoration is scientific understanding of the geologic history and processes of the coastal zone region, including interactions between the rivers, wetlands, coast, and inner shelf.

A variety of geophysical studies and mapping of Late Quaternary sedimentary framework and coastal processes by U.S. Geological Survey and other scientists during the past 50 years document that the Louisiana delta plain is the product of a complex history of cyclic delta switching by the Mississippi River and its distributaries over the past $\sim 10,000$ years that resulted in laterally overlapping deltaic depocenters. The interactions among riverine, coastal, and inner shelf processes have been superimposed on the Holocene transgression resulting in distinctive landforms and sedimentary sequences.

Four Holocene shelf-phase delta complexes have been identified using seismic reflection data and vibracores. Each delta complex is bounded by transgressive surfaces. Following each cycle of deposition and abandonment, the delta lobes undergo regional subsidence and marine reworking that forms transgressive coastal systems and barrier islands. Ultimately, the distal end of each of the abandoned delta lobes is marked by submerged marine sand bodies representing drowned barriers. These sand bodies (e.g. Ship Shoal, Outer Shoal, Trinity Shoal, Tiger Shoal, St. 
Bernard Shoal) offer the largest volumes and highest quality sand for beach nourishment and shoreline and wetlands restoration.

These four large sand shoals on inner continental shelf, representing the reworked remnants of former prograded deltaic headlands that existed on the continental shelf at lower sea level, were generated in the retreat path of the Mississippi River delta plain during the Holocene transgression. Penland and others (1989) have shown these sand bodies represent former shoreline positions associated with lower still stands in sea level. Short periods of rapid relative sea-level rise led to the transgressive submergence of the shorelines which today can be recognized at the $-10 \mathrm{~m}$ to $-20 \mathrm{~m}$ isobaths on the Louisiana continental shelf. Trinity Shoal and Ship Shoal represent the $-10 \mathrm{~m}$ middle-to-late Holocene shoreline trend, whereas Outer Shoal and the St. Bernard Shoals define the -20 m early Holocene shoreline trend (Penland and others, 1989). Collectively, these sand shoals constitute a large volume of high quality sandy sediment potentially suitable for barrier island nourishment and coastal restoration.

The USGS has actively supported coastal and wetlands geologic research for the past two decades in partnership with universities (e.g., Louisiana State University, University of New Orleans), state agencies (e.g. Louisiana Geological Survey, Louisiana Department of Natural Resources), and private organizations (Williams and others, 1992a,b; Williams and Cichon, 1993; List and others, 1994). These studies have focused on regional-scale mapping of coastal and wetland change and developing a better understanding of the processes that cause coastal erosion and wetlands loss, particularly the rapid deterioration of Louisiana's barrier islands, estuaries, and wetlands environments. With a better understanding of these processes, the ability to model and predict erosion and wetlands loss will improve. More accurate predictions will, in turn, allow for proper management of coastal resources. Improved predictions will also allow for better assessments of the utility of different restoration alternatives.

Note: Much of the preceding descriptive material is from the recent publication, "Mississippi River Delta Plain, Louisiana Coast and Inner Shelf: Holocene Geologic Framework and Processes". Please refer to that report for more information about the delta plain geologic history and processes and a complete listing of references, many of which are included in the references section of this report.

Citation: Williams, S.J., Kulp, M., Penland, S., Kindinger, J.L., and Flocks, J.G., (in press), Mississippi River Delta Plain, Louisiana Coast and Inner Shelf: Holocene Geologic Framework and Processes, chapter in Gulf of Mexico, its origins, water, biota, and human impacts (C. Holmes and W. Tunnell, eds.), Texas A\&M Press Books.

The shoreline change maps of the Isles Derniers below are examples from U.S. Geological Survey Digital Data Series 79 (Williams and others, 2003), Coastal Erosion and Wetland Change in Louisiana: Selected USGS Products, depict historic shoreline change of the Louisiana coast and are provided as additional information demonstrating how the delta plain has undergone dramatic change due to a complex combination of natural and man-made processes. 
Shoreline for Isles Dernieres Barrier

Island Arc, 1887 (republished from

Williams and others, 2003; U.S. Geological

Survey Digital Data Series 79)

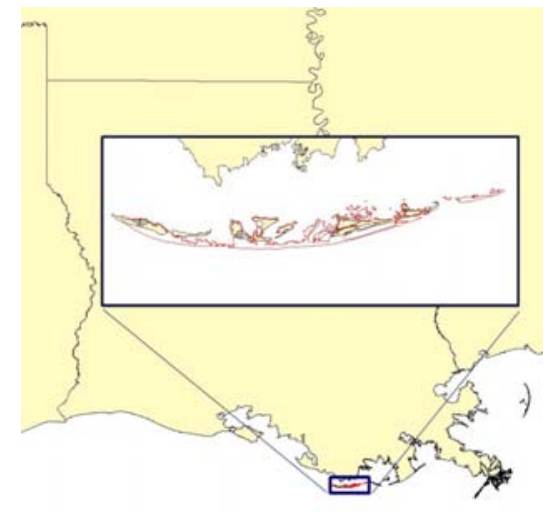

1887
Shoreline for Isles Dernieres Barrier Island Arc, 1996 (republished from Williams and others, 2003; U.S. Geological Survey Digital Data Series 79)

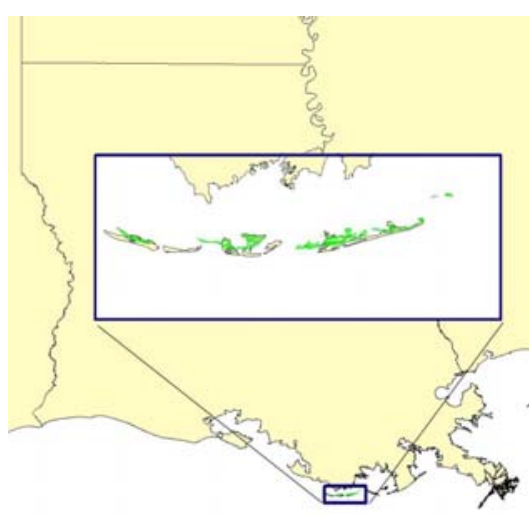

1996

\section{Data at a Glance}

Scatter diagram of superimposed plots of mean sediment grain size (x-axis) vs. sorting (yaxis) for the Extracted data (in blue) and the Parsed data (in red) along the Louisiana coastal margin from USGS Data Series 146. 


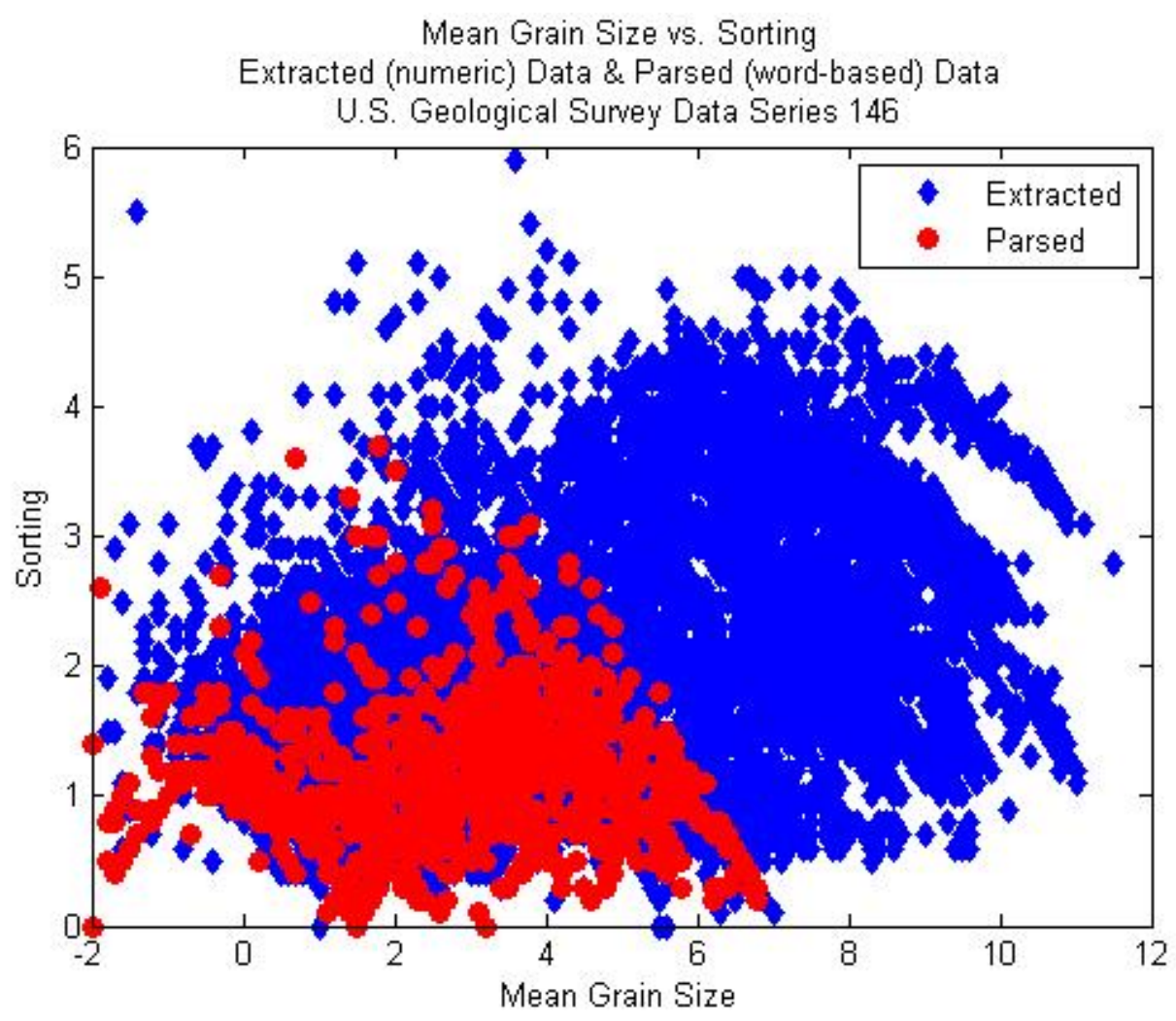

\section{uSSEABED Overview}

Publications in the usSEABED data release series, represent the combined efforts of the USGS and several other government agencies and universities to provide a unified resource for accessing and preserving records of sea floor geologic information and sediment texture data.

This publication illustrates the uses of the usSEABED database for GIS applications, while offering additional insight into the resources and data available from the USGS and its collaborative institutions. 


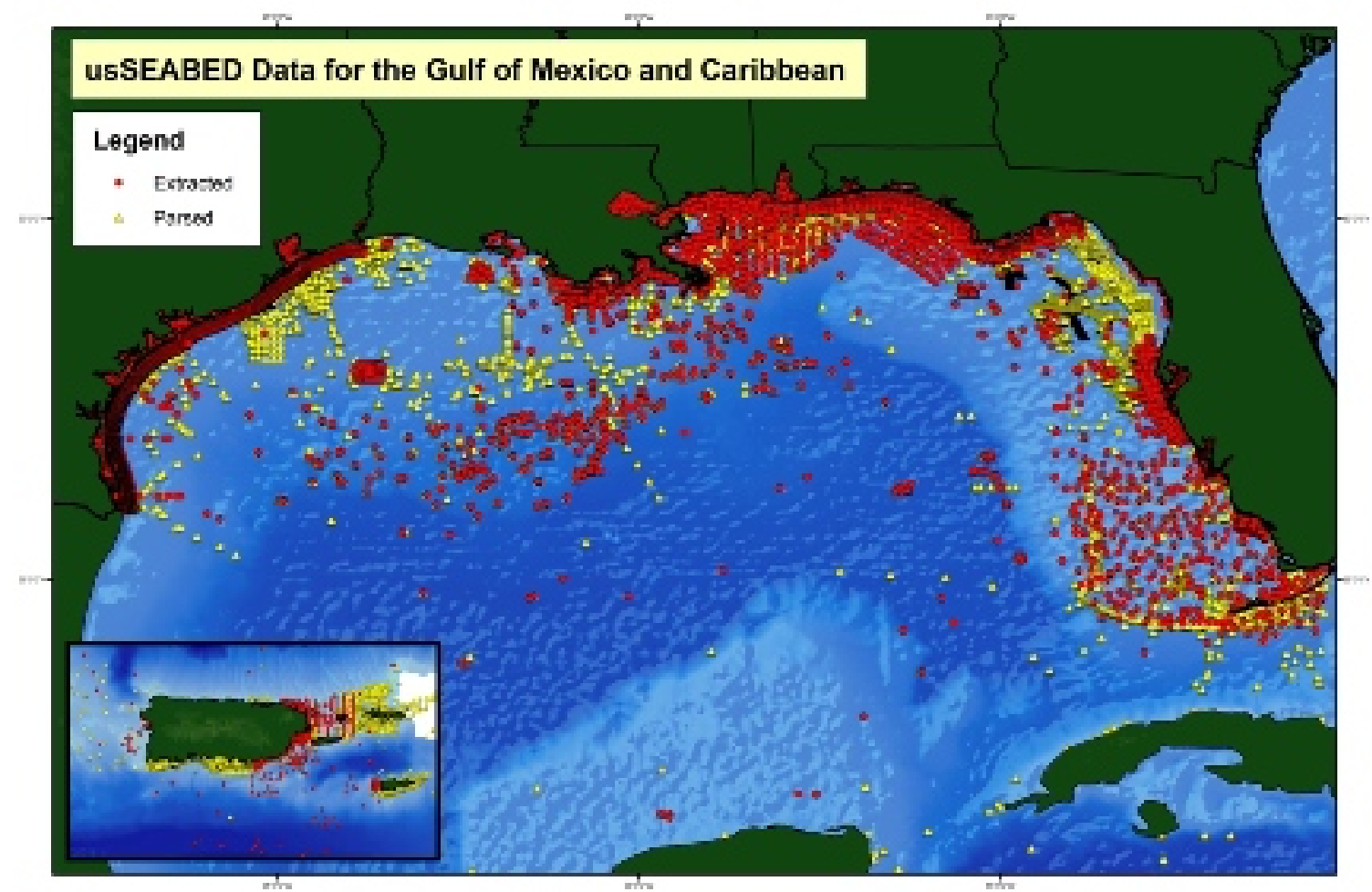

Sediment data points along the Gulf coast of the United States (Buczkowski and others, 2006).

This report focuses on the Louisiana delta plain offshore region, an area that has been intensely studied by the USGS for many years. The goal of these studies has been to better understand the geologic history and processes of the coastal and wetland landscape features as well as offshore components of the delta plain.

The objectives of the Marine Aggregate Resources and Processes project are to produce a series of new geologic maps and reports of the sea floor that will provide scientific insights into the character and geologic development of U.S. continental margins and to use these maps and information to assess the potential availability of offshore sand and gravel resources. The mapping and aggregate resource assessments are being conducted on a national scale using the usSEABED data base as described in Williams and others (2003b). Potential uses for these data include: (1) defining the geological variability of the sea floor, in relation to benthic habitat diversity; (2) improving our understanding of the processes that control the distribution and transport of bottom sediments and benthic habitats; (3) locating aggregate resources for beach nourishment and industrial applications; and (4) providing a detailed geospatial framework for future marine science research, monitoring, and management activities. The initial assessments are in progress for the New York Bight and Louisiana offshore areas.

This report is based on data contained in U.S. Geological Survey Data Series 146 (Buczkowski and others, 2006) and shows examples of GIS products that are possible using usSEABED. All data are intended to be GIS-ready; that is the data should not require any additional cleanup, formatting, or renaming of fields in order to use the data in a Geographic Information System. This project employs the Environmental Systems Research Institute's (ESRI) ArcView ${ }^{\mathrm{TM}}$ software. Many of these maps were made as part of the ongoing USGS study to assess marine aggregate resources offshore Louisiana, but these maps can serve many other purposes. The marine science community, educators, students and others are encouraged to use these data to generate GIS products for their own purposes. 


\section{Applications of usSEABED Data}

The usSEABED data set has many potential uses. Illustrated here are three applications of how the data may be used. Further examples of maps that may be made with the data included on this CD-ROM may be found in the Browse Maps section of this publication.

Since the passing of the Sustainable Fisheries Act of 1996, Regional Fishery Management councils around the U.S. have been describing and identifying essential fish habitat (EFH) in their respective regions to more effectively manage the Nation's fisheries. Congress defined EFH as "those waters and substrate necessary to fish for spawning, breeding, feeding or growth to maturity." 


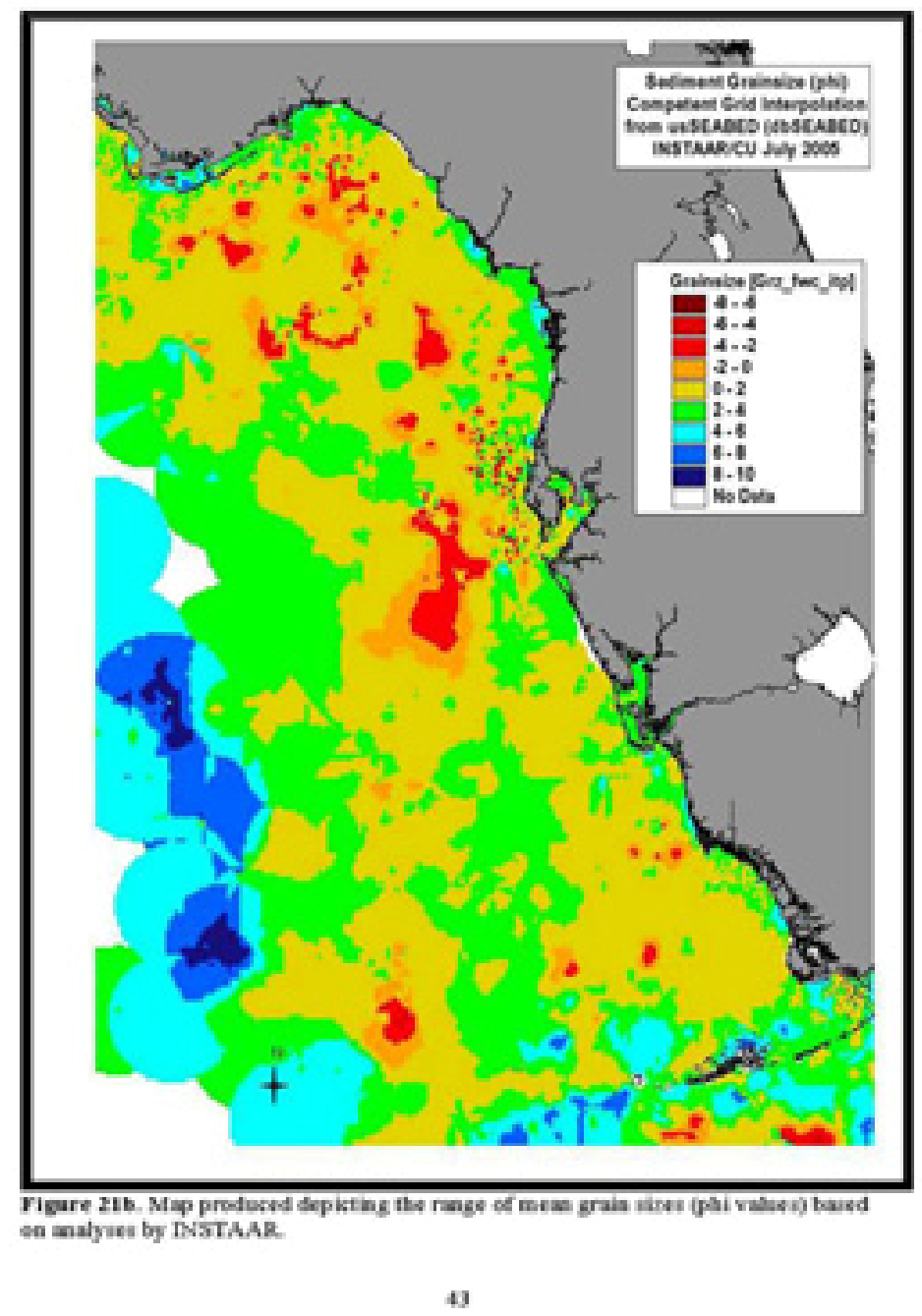

Fish Habitat Mapping - The Florida Fish and Wildlife Conservation Commission in collaboration with other groups modeled and mapped water-column and benthic habitat data in relation to catch and effort data associated with the pink shrimp fishery on the West Florida Shelf (WFS). Some of the water-column habitat data included bottom temperature, bottom current speed and current direction. Sediment distribution maps produced using usSEABED data were produced by INSTAAR of the University of Colorado at Boulder. Suitability functions created from the fishery data were used to predict catch rates (CPUEs) in relation to depth, aspect, bottom type, bottom temperature, bottom current speed, current direction, and VMS zones. Habitat suitability models (HSM) linked to geographic information systems (GIS) were used to predict spatial distributions and abundances of pink shrimp monthly from March 2004 to June 2005. This multi-institution project is intended to foster new relationships between public institutions and private business, and can benefit both the fishing industry and fisheries management (Rubec and others, 2005). 


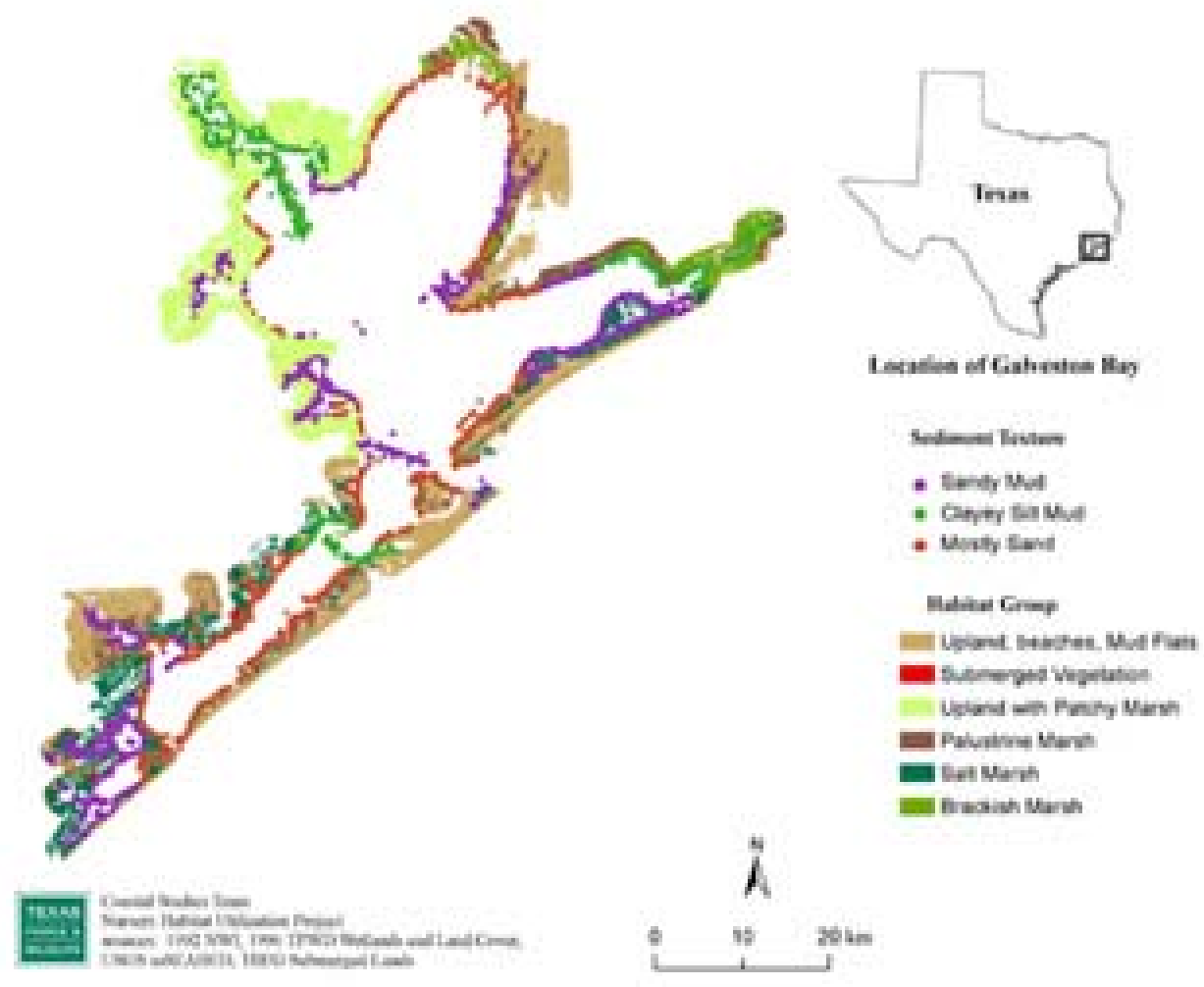

The Texas Parks and Wildlife Department, funded in part by a US Fish and Wildlife Service Wildlife Grant, is conducting a spatial and temporal evaluation of fish and shellfish nursery habitat in two Texas bay systems: Galveston and San Antonio. The Department's Coastal Fisheries Division, Coastal Studies Team is using usSEABED sediment information from USGS DS-146, in part to characterize shoreline bottom texture (sand, silt, mud, clay, or a mixture), which aids in differentiating back-bay habitats. 


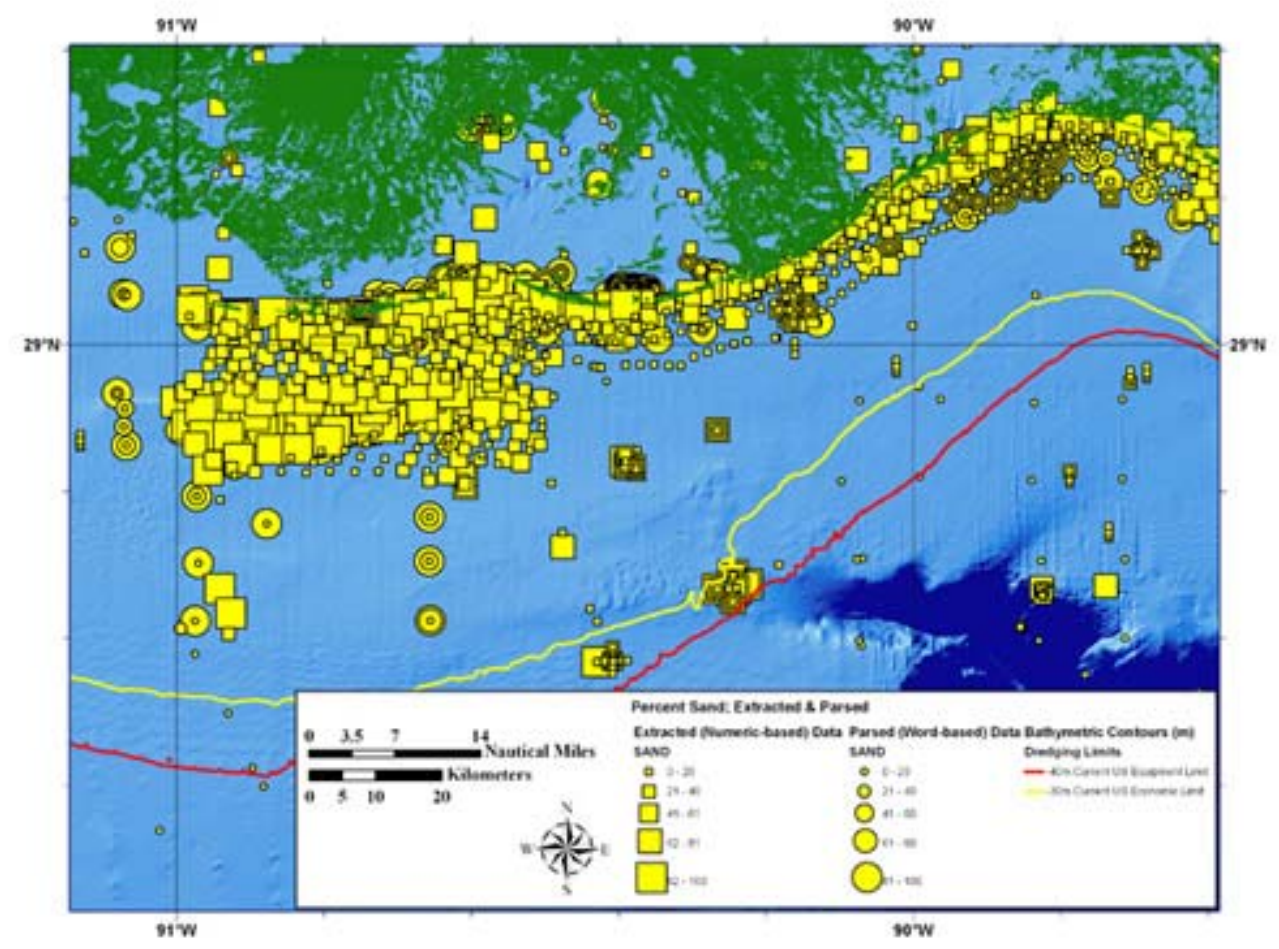

Sand and Gravel Resources for Beach Nourishment - Beach nourishment, a method of dredging sand from offshore areas and pumping it ashore to widen and elevate beaches and dunes is often viewed as a cost-effective and environmentally acceptable method for use on developed coasts to mitigate erosion, reduce storm and flooding risk, enhance recreation, and restore degraded ecosystems. For beach nourishment to be viable, however, large volumes of high quality sand are necessary and the sand deposits must be located reasonably close to the beaches being nourished. Also, the sand deposits ideally should be in water depths ranging from approximately $-10 \mathrm{~m}$, an approximate "close-out depth" for nearshore sediment transport, to $-40 \mathrm{~m}$, an approximate current limit of U.S. commercial dredging. The map above shows the percent sand composition of usSEABED data points on the Louisiana inner shelf in relation to the current water depth dredge limits. For beach nourishment, $>90 \%$ sand is optimal for best performance . 


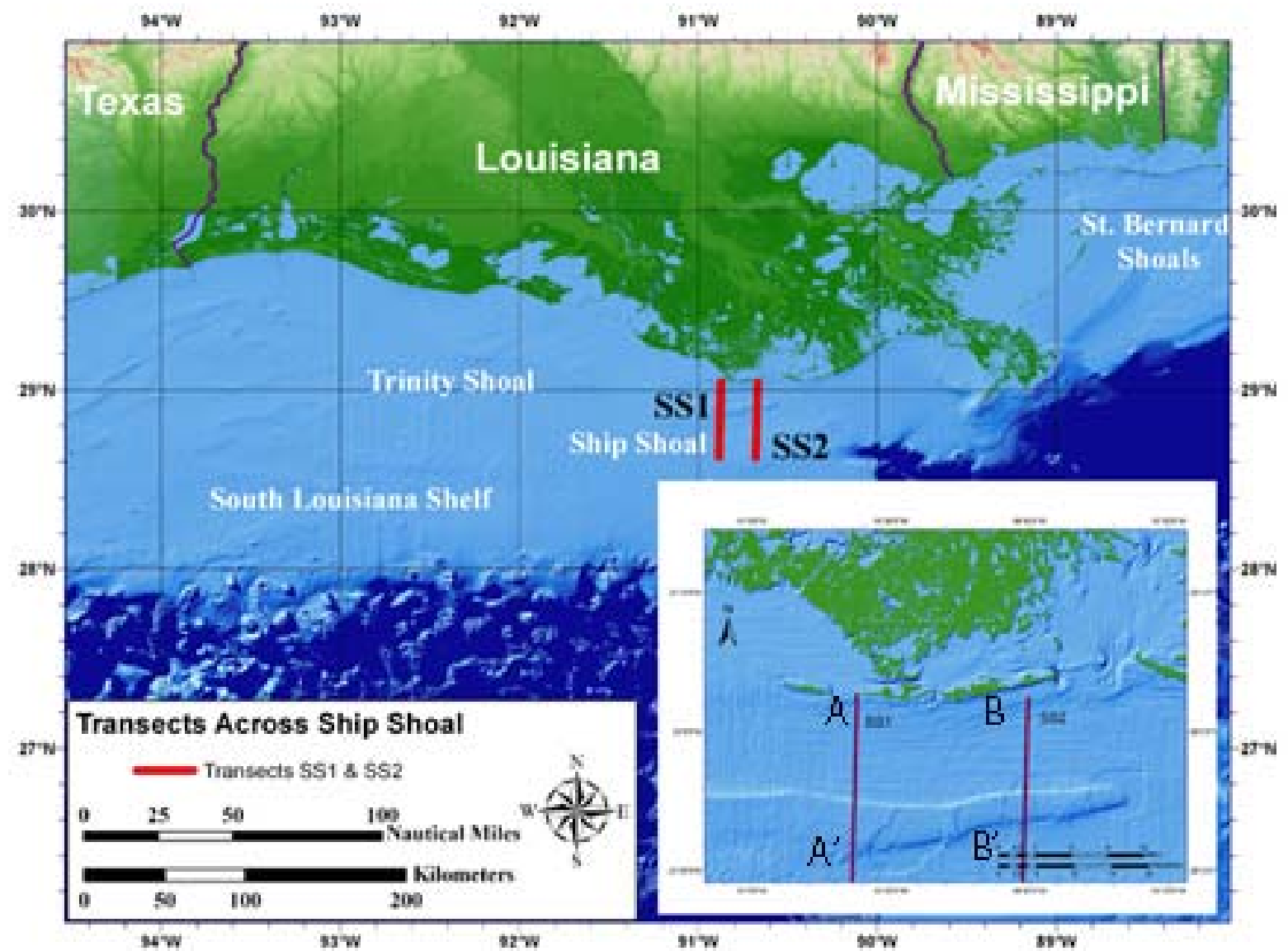

Planning Sea-Floor Routes and Utilities Placement - The Louisiana shelf is the product of a complex geologic history and dynamic oceanographic processes, dominated by the Holocene marine transgression during the past 20,000 years and cyclic shifts of the Mississippi River over the past 7,000 years. Engineering activities (i.e., oil and gas production, LNG facilities, pipeline and cable routes, potential wind-energy-generation sites) are increasing within these regions as infrastructure and resource planning tries to keep pace with growing demands. The shore-normal profiles SS1 and SS2 depict the seafloor morphology from the shoreface to $50 \mathrm{~km}$ seaward of Ship Shoal. Plots of sediment character below the profiles show the shoreface is predominantly muddy sand and Ship Shoal is nearly 100 percent sand. 


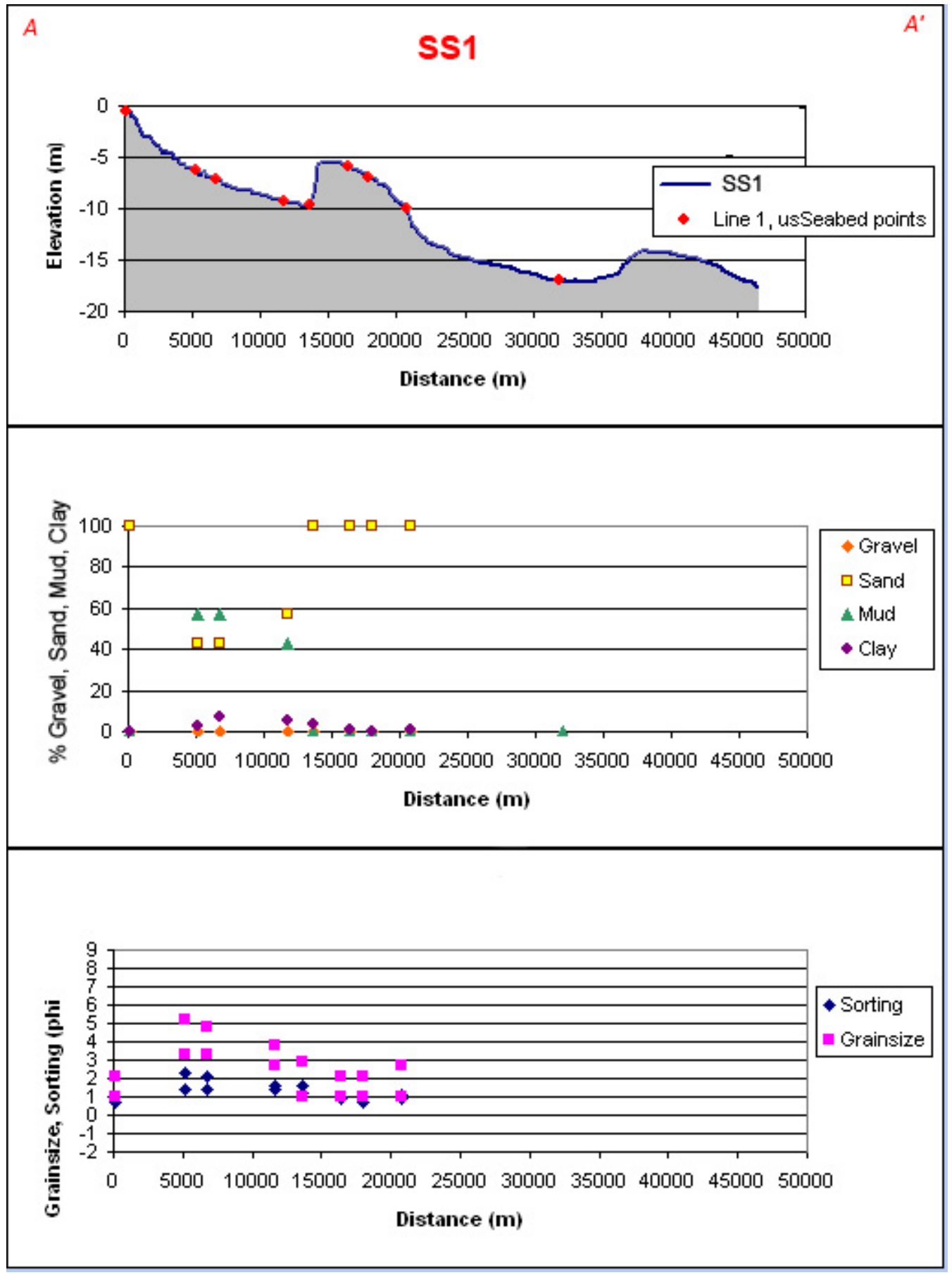




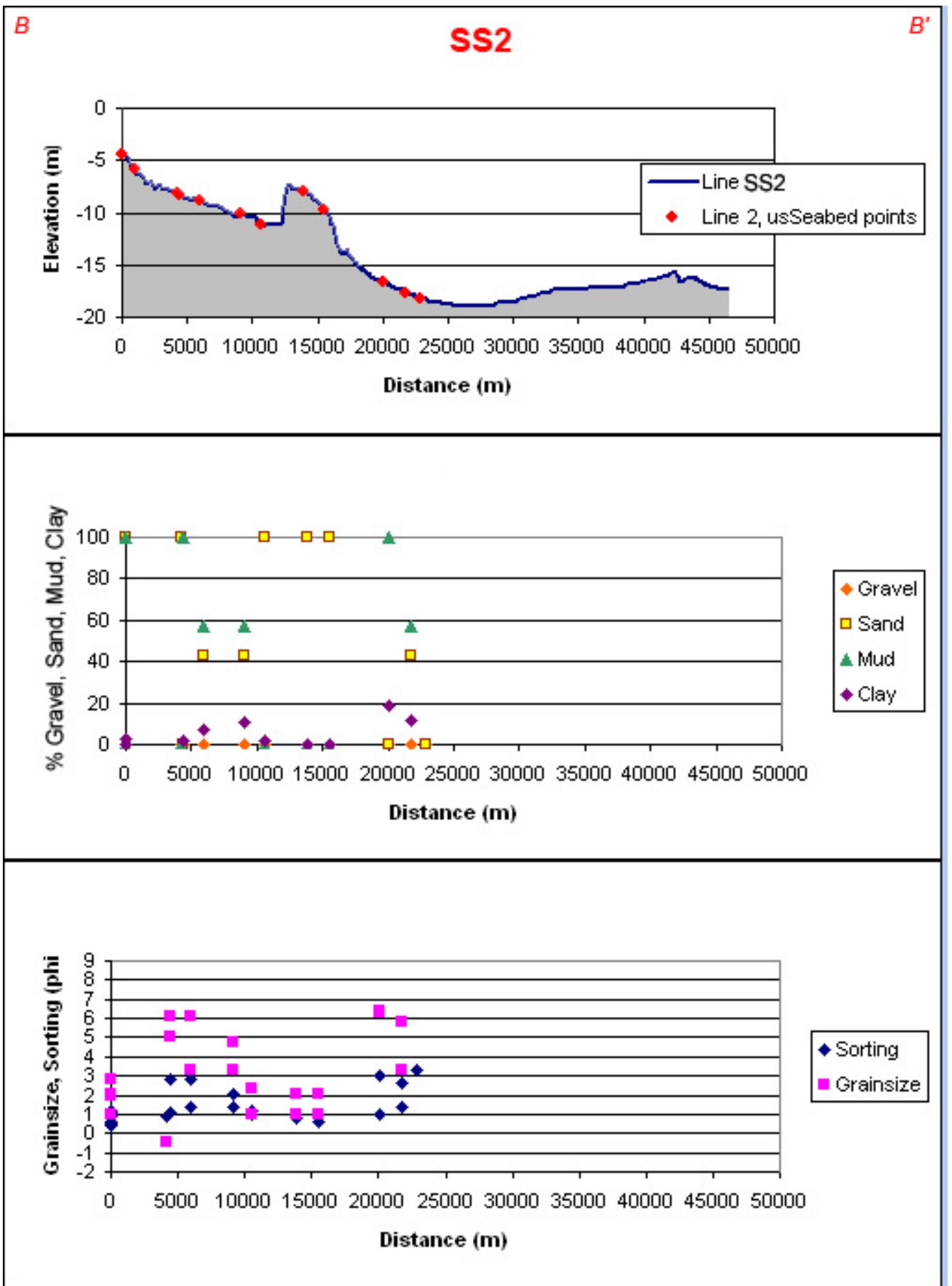




\section{Nomenclature}

Nomenclature describing sediment texture distributions is important to geologists and sedimentologists because grain size is the most basic attribute of sediments. Traditionally, geologists have divided sediments into four size fractions that include gravel, sand, silt, and clay, and classified these sediments based on ratios of the various proportions of the fractions. Definitions of the fractions have long been standardized to the grade scale described by Wentworth (1922), and the size data compiled in this report conform to these definitions. Specifically, according to the Wentworth grade scale (PDF version) gravel-sized particles have a nominal diameter of $2 \mathrm{~mm}$; sand-sized particles have nominal diameters from $<2 \mathrm{~mm}$ to $>62.5 \mu \mathrm{m}$; silt-sized particles have nominal diameters from $<62.5 \mu \mathrm{m}$ to $>4 \mu \mathrm{m}$; and clay is $<4 \mu \mathrm{m}$.

Although several classification schemes have been adopted to describe the approximate relationship between the size fractions, most sedimentologists use one of the systems described either by Shepard (1954) or Folk $(1954,1974)$. The original scheme devised by Shepard (1954) utilized a single ternary diagram with sand, silt, and clay in the corners to graphically show the relative proportions among these three grades within a sample. This scheme, however, does not allow for sediments with significant amounts of gravel. Therefore, Shepard's classification scheme was subsequently modified by the addition of a second ternary diagram to account for the gravel fraction (Schlee, 1973). The system devised by Folk $(1954,1974)$ is also based on two triangular diagrams, but it has 21 major categories, and uses the term mud (defined as silt plus clay). The patterns within the triangles of both systems differ, as does the emphasis placed on gravel. For example, in the system described by Shepard, gravelly sediments have more than 10 percent gravel; in Folk's system, slightly gravelly sediments have as little as 0.01 percent gravel. Folk's classification scheme stresses gravel because its concentration is a function of the highest current velocity at the time of deposition, together with the maximum grain size of the detritus that is available; Shepard's classification scheme emphasizes the ratios of sand, silt, and clay because they reflect sorting and reworking (Poppe and others, 2005).

Although most source data sets in this compilation (see the Data Catalog) contain raw grain size data, several provide only verbal descriptions of the sea-floor character. Some of these verbal descriptions are somewhat detailed, such as in the lithologic descriptions file from the USGS Continental Margin Program; others are quite abbreviated, as in the one-word descriptors supplied with the NOAA Hydrographic Database. Furthermore, most source data sets contain sediment classifications that were assigned by scientists as part of the original study. These word-based data sets have been related to numeric values for inclusion in the usSEABED data sets. Users are encouraged to review the Data Dictionary section and the usSEABED website for a thorough explanation.

Most of the samples compiled in this report were collected using some type of grab sampler, but some were obtained by coring or with dredges. When core samples are included, or when changes in the sediment type with depth are present in a grab sample, only the analysis from the uppermost sediment type was used when mapping surficial sediment distributions. Similarly, samples collected with chain dredges are probably texturally biased and care must be taken with the use of this data.

The USGS has traditionally defined surficial samples as those sediments collected from the interval 0-2 $\mathrm{cm}$ below the sediment/water interface. Although many of the samples in this compilation conform to this standard, some of the studies did not define this interval or reported intervals with slightly greater bottom depths (e.g. 0-5 cm). Concerned users should consult the original source references or the metadata files provided in this report. 
Plotting routines (Matlab based) for the Shepard and Schlee classifications mentioned above, are available in the For Educators section of this publication. These routines allow users to plot their own ternary diagrams.

\section{Coastal Change in Louisiana}

These maps depicting historic shoreline change of the Louisiana coast, from U.S. Geological Survey Digital Data Series DDS-79 (Williams and others, 2003), Coastal Erosion and Wetland Change in Louisiana: Selected USGS Products ONLINE, are provided as additional information.

The USGS, as the Nation's primary science organization, has conducted research, mapping studies and monitoring in Louisiana for many years. Three of the major studies undertaken were the Louisiana Barrier Island Erosion Study, a cooperative effort with the Louisiana Geological Survey that spanned 1986 to 1990. A second study, the Louisiana Wetland Loss Study, was done cooperatively with the USGS National Wetlands Research Center Lafayette and scientists at Louisiana State University. The third and most recent study involved University of New Orleans scientists and was focused on the geologic framework and processes of the Lake Pontchartrain basin. Additional studies by the USGS and partners are continuing to map shoreline and wetland change, investigate subsidence processes responsible for the high rates of relative sea-level rise across the south Louisiana region, and assess offshore sand resources.

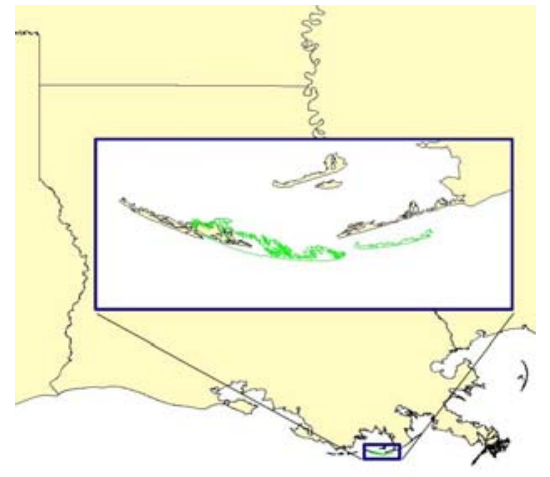

Shoreline for Timbalier Barrier Island Arc, 1887 and 1996

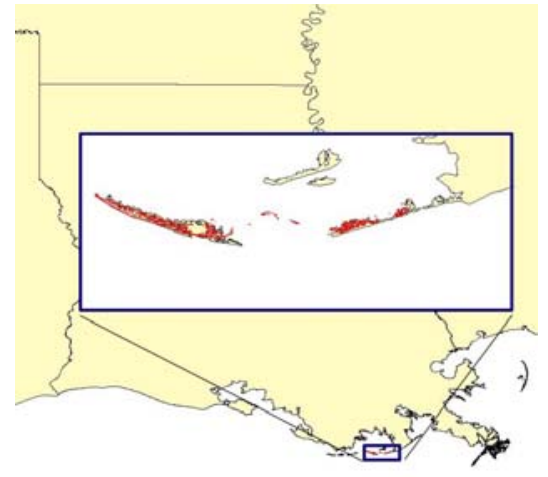

1996 


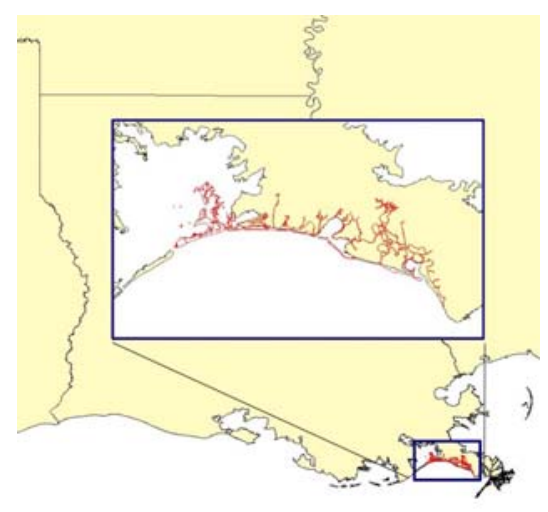

1884

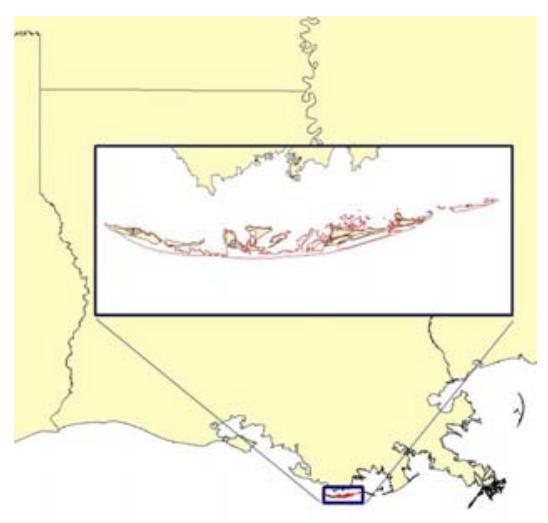

1887
Shoreline for Plaquemines

Barrier Island System, 1884 and 1996

Shoreline for Isles Dernieres

Barrier Island Arc, 1887 and 1996

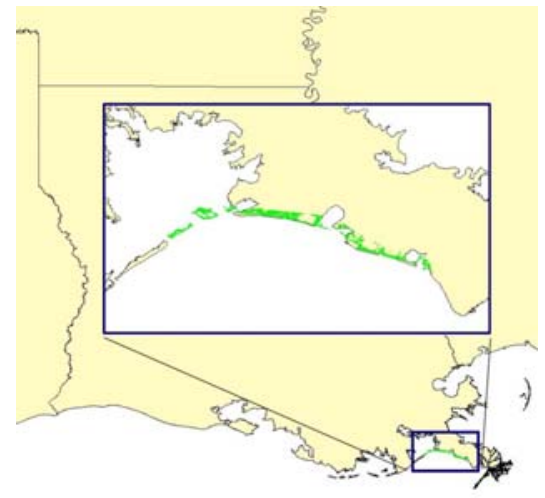

1996

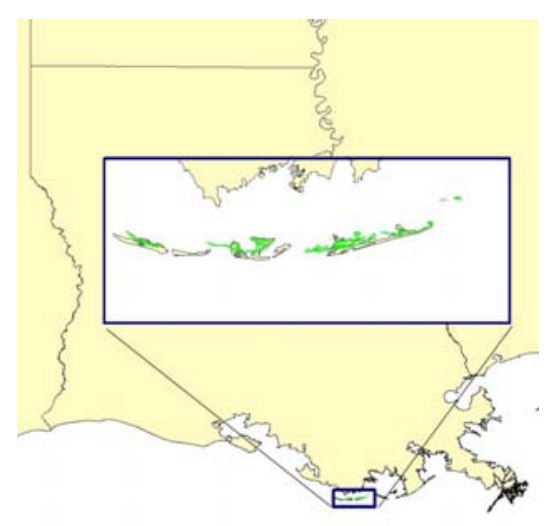

1996 


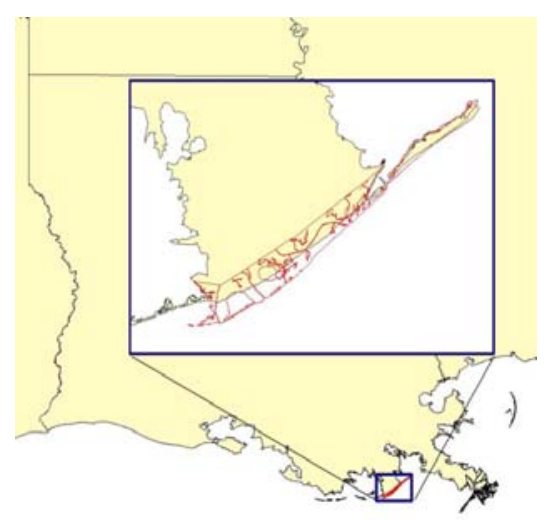

1887

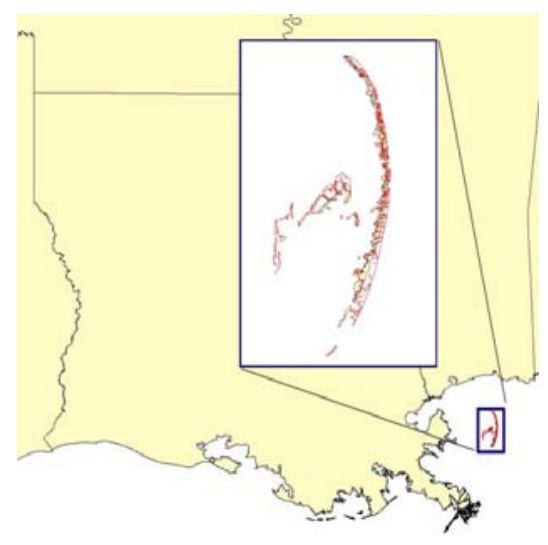

1855
Shoreline for Caminada-Moreau Headland, 1887 and 1996

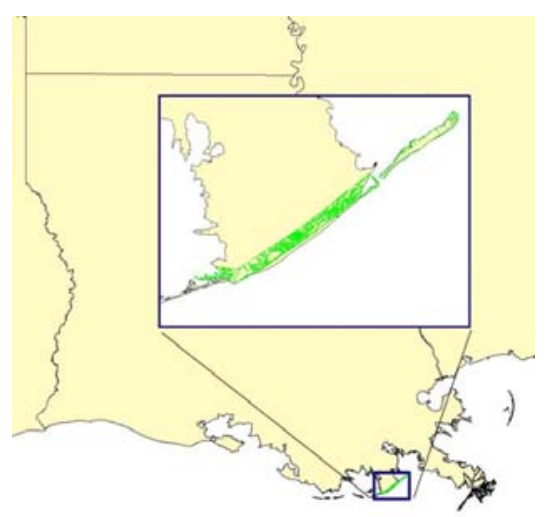

1996
Shoreline for North Chandeleur

Barrier Island Arc, 1855 and 1999

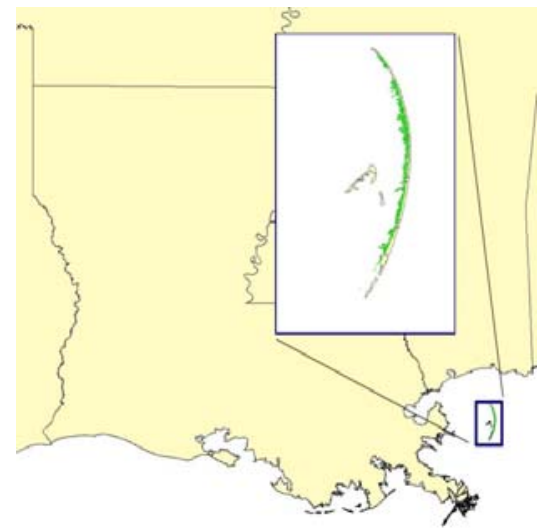

1999 


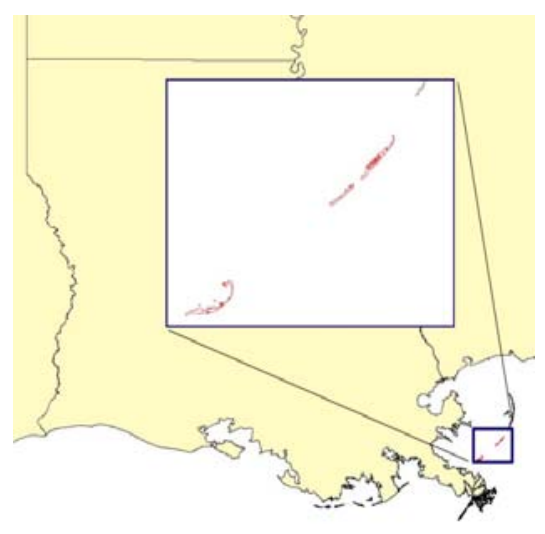

1855
Shoreline for South Chandeleur Barrier Island Arc, 1855 and 1999

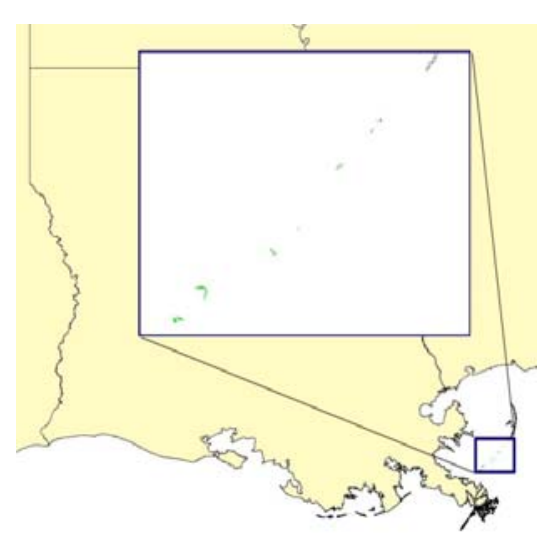

1999

\section{Data Dictionary}

Geologic sedimentary-character data included within this Open-File Report were previously released as part of the USGS Data Series-146, usSEABED: Gulf of Mexico Surficial Sediment Data Release (Buczkowski and others, 2006). That publication was the first release of the Gulf of Mexico coast data from the usSEABED database. That database contains data and information that forms the scientific foundation for the sediment characterization found within that publication. Below you will find a description of the categories, themes and units held within the dataset. usSEABED information is categorized into 12 data themes. A list of data themes is given in Table A. The thematic basis of the values found in the outputs can be found in field 11 ("DataType")(Table B) of the extracted (_EXT), parsed (_PRS), and calculated (_CLC) output files. Information on contribution of each source report is in the accompanying metadata files.

\begin{tabular}{|l|l|}
\hline \multicolumn{2}{|c|}{ Table A. Key to data themes in usSEABED output files } \\
\hline \hline \multicolumn{1}{|c|}{ Acronym } & \\
\hline ACU & Acoustic properties \\
\hline BIO & Biota \\
\hline CMP & Sediment composition analyses \\
\hline COL & Color \\
\hline GRZ & Grain size analysis results \\
\hline GTC & Geotechnic properties \\
\hline LTH & Lithology \\
\hline MSL & Multisensor core logger \\
\hline
\end{tabular}




\begin{tabular}{|l|l|}
\hline PET & Grain petrology \\
\hline SFT & Seafloor type descriptions \\
\hline TXG & Graphical texture statistics \\
\hline TXR & Texture statistics \\
\hline
\end{tabular}

\section{Relational Keys}

The usSEABED data file types are linked relationally by the foreign keys: DataSetKey (for individual data sets), SiteKey (for individual sites), and the SampleKey (for individual analyses). The DataSetKey field gives the relationship of the data to the original source. The tables can be loaded into a relational database (RDB), relationships may be constructed, and the tables may be joined using the keys.

\section{Source data(_SRC)}

Information about the original data are in the source (_SRC) file, including links to metadata about the original data. Each of the output data files discussed below is linked to the _SRC file by the DataSetKey field.

\section{Textural and other basic information (_EXT,_PRS, _CLC)}

Textural, statistical, geochemical, geophysical, dominant component, and color information are held in three separate, but similar, data files, based on the type of data:_EXT,_PRS,_CLC. The three data file types have the same fields (Table B) and can be combined for more extensive coverage of the seafloor. It is important for users to understand the inherent limitations of each type of file in order to choose the best data file, or combination of data files appropriate for a particular use.

\section{Extracted data (_EXT)}

The data file with the EXT tag is the extracted data: those data from strictly performed,

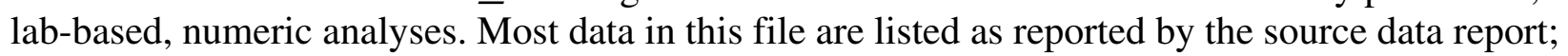
only minor unit changes are performed or assumptions made about the thickness of the sediment analyzed based on the sampler type. Typical data themes include textural classes and statistics (TXR: gravel, sand, silt, clay, mud, and various statistics), phi grain-size classes (GRZ), chemical composition (CMP), acoustic measurements (ACU), color (COL), and geotechnical parameters (GTC). The _EXT file is based on rigorous lab-determined values and forms the most reliable data sets. Limitations, however, exist due to the uncertainty of the sample tested. For example, were the analyses performed on whole samples or only on the matrix, possibly with larger particles ignored?

\section{Parsed data (_PRS)}

Numeric data obtained from verbal logs from core descriptions, shipboard notes, and (or) photographic descriptions are held in the parsed data set (_PRS). The input data are maintained using the terms employed by the original researchers and are coded using phonetically sensible terms for easier processing by dbSEABED. Longer descriptions may have the data divided by 
theme (Table A). The descriptions often include information on associated biota, sea floor features, and structure. Typical data themes for the parsed data set are lithologic descriptions (LTH), biology (BIO), color (COL), and (or) sea floor type (SFT, descriptions from photos or videos). The values in the parsed data file are calculated using the dbSEABED parser that assigns field values based on the form and content of a description. See the original DS- 146 publication (Buczkowski and others, 2006) for additional information on the processing and fuzzy set theory.

The parsing process has been tested and calibrated by comparing the outputs against analytical results for the same samples. Due to the nature of visual descriptions by observers and the use of fuzzy set theory in the parser, the output data show the degree of representation in the sample, or percent abundance values. An assumption in the process is that the output degrees of representation reflect absolute abundances to some degree of accuracy. The calibrations provide information on that accuracy. Although at first sight the descriptive results in the parsed file may seem less accurate than measured values in the extracted file, they are frequently more representative of the sample and seabed as a whole, as they include description of objects such as shells, stones, algae, and other objects (Table C) that are a textural component of the seabed and which are often left out of laboratory analyses, particularly when a machine analysis is employed.

\section{Calculated data (_CLC)}

For the extracted and parsed data, some values are not reported by the original source, but can be calculated directly or estimated by standard derivative equations using assumptions about the conditions or variables. These values are reported in the calculated (_CLC) data files. Although the calculated (_CLC) data can be combined with the extracted and the parsed (Table B), they are the least reliable of the three data file types and should be used with caution.

\section{Component/feature and facies data (_CMP,_FAC)}

Two usSEABED data files contain information about the presence of certain sea floor features, compositional content, biota, and sediment structure. These use major synonyms defined by the thesaurus in the dbSEABED parsing software, which clusters comparable descriptive terms together (granite represents granite, aplite, granodiorite, pegmatite, while laminated represents laminated, laminations, or lamina). Individual components and features (terms like feldspar, phosphorite, bivalves, seagrass, and wood) are held in the _CMP data file (Table D). Appropriately combined components are held in the facies (_FAC) data files (Table E). As with the parsed data files, the values held within the _CMP and_FAC files are the results of filters based on fuzzy set membership to chosen sets, and represent a measure of truth about the attribute, not percentages or defined values. These files only indicate presence, not absence, of material; it is rare that a report might state, "no bivalves" or "no phosphorite."

The _CMP file contains information about compositional content (individual minerals, rocks), genesis (terrigenous, carbonate), and certain biota. These components are internally evaluated and the value for each attribute is based solely on the relationships of attributes within the original description. The flora and fauna included in the compositional components are those that may have an effect on textural determinations in the _PRS data file, such as halimeda, bivalves, or foraminifera (Table C). The values within these attribute fields range between 0 (no membership, probably due to no information), to 100 (complete membership, shell hash $=100$ to the shell debris set).

The _CMP file also includes information on sea floor features such as bedforms, fissures, internal structure (bedding, bioturbation), and other flora and fauna. Unlike the compositional 
content information, which is construed as an abundance within the sample, these attributes are an intensity of development or density of occurrence relative to scales of development or density of occurrence observed elsewhere. The flora and fauna included in the feature category are softbodied, for example, those that do not have an input on the textural determination within the_PRS data files, such as kelp, ophiuroids, or annelids. Values within the attribute fields range from 0 (no membership, possibly due to no information) up to $100 \%$ (maximum development). In contrast to the situation with component abundances, the sum of feature intensities in a sample is allowed to exceed $100 \%$.

The 100 most common components in the U.S. EEZ are given in the _CMP file, and those attributes with "_F" denote features. Table D lists the components and gives basic forms of descriptive terms that may trigger membership for each. Included in this file are 27 components that are included in the facies (_FAC) file only.

The second file, the facies file (_FAC), is created from components only, similar to the _CMP file. This file configures multiple components into appropriate groups or facies, such as igneous, metamorphic, ooze, foraminifera, and others. The dbSEABED processing software is restricted to a maximum of six components per facies. Table $E$ lists the facies type and the components that comprise each facies group.

Again, these files only indicate presence, not absence, of material; it is rare that a report might state, "no bivalves" or "no phosphorite". The values within this attribute field range between 0 (no membership, probably due to no information), to 100 (complete membership, for example, schist $=100$ to the metamorphic set).

\section{Relationship between the _PRS and_CMP outputs}

The dbSEABED processing software recognizes that many skeletonized biota, such as halimeda, rhodoliths, shells (broken and unbroken), and others often comprise a sediment sample. Such biological terms are included in the parsing of the textural values. To see the selected biota with textural implications, see Table $C$. When using the parsed data, it may be important to crosscheck with the component file using the relational foreign keys (SiteKey, SampleKey) to determine if biota are to be included in the textural outputs.

Within the _PRS file, the "seabed class" and "class membership" fields indicate the dominant compositional class and the fuzzy set membership of a sample to that class. Other components and mined information may also be listed for that sample in the _CMP file, linked by the relational keys.

\begin{tabular}{|c|c|c|c|c|}
\hline Field Name & Parameter & Data Format & $\begin{array}{l}\text { Units, Range, } \\
\text { Meaning }\end{array}$ & Comment \\
\hline Latitude & Latitude & $\begin{array}{l}\text { Decimal } \\
00.00000\end{array}$ & $\begin{array}{l}\text { Decimal } \\
\text { degrees, } 90^{\circ} \text { to - } \\
90^{\circ} \text { range }\end{array}$ & WGS 84 Spheroid. \\
\hline
\end{tabular}




\begin{tabular}{|c|c|c|c|c|}
\hline Longitude & Longitude & $\begin{array}{l}\text { Decimal } \\
000.00000\end{array}$ & $\begin{array}{l}\text { Decimal } \\
\text { degrees, }-180^{\circ} \\
\text { to } 180^{\circ} \text { range }\end{array}$ & WGS 84 Spheroid. \\
\hline WaterDepth & Water depth & $\begin{array}{l}\text { Integer } \\
00000\end{array}$ & Meters & Not always corrected for tides. \\
\hline SampleTop & Sample top & $\begin{array}{l}\text { Decimal } \\
000.00\end{array}$ & $\begin{array}{l}\text { Meters below } \\
\text { seabed surface }\end{array}$ & $\begin{array}{l}\text { Sample top as noted in source } \\
\text { report. }\end{array}$ \\
\hline SampleBase & Sample base & $\begin{array}{l}\text { Decimal } \\
000.00\end{array}$ & $\begin{array}{l}\text { Meters below } \\
\text { seabed surface }\end{array}$ & $\begin{array}{l}\text { Sample bottom as noted in } \\
\text { source report. }\end{array}$ \\
\hline SiteName & Site name & $\begin{array}{l}\text { Character } \\
\text { XXX: XXX }\end{array}$ & $\begin{array}{l}\text { Survey or } \\
\text { laboratory code } \\
\text { for the sampling } \\
\text { site }\end{array}$ & $\begin{array}{l}\text { Not unique; site name as given } \\
\text { in report; sometimes linked to } \\
\text { cruise name or other information } \\
\text { to decrease site name overlap. }\end{array}$ \\
\hline DataSetKey & $\begin{array}{l}\text { Dataset } \\
\text { number key }\end{array}$ & Integer 000 & For audit only & $\begin{array}{l}\text { Relational key to_SRC file; } \\
\text { _SRC file contains links to } \\
\text { source metadata. }\end{array}$ \\
\hline SiteKey & $\begin{array}{l}\text { Site number } \\
\text { key }\end{array}$ & $\begin{array}{l}\text { Integer } \\
0000000\end{array}$ & For audit only & $\begin{array}{l}\text { Relational key to other data files. } \\
\text { Each site counted sequentially as } \\
\text { total output; core data may have } \\
\text { more than one sample per site. }\end{array}$ \\
\hline SampleKey & $\begin{array}{l}\text { Sample } \\
\text { number key }\end{array}$ & $\begin{array}{l}\text { Integer } \\
0000000\end{array}$ & For audit only & $\begin{array}{l}\text { Relational key to other data files. } \\
\text { Each site counted sequentially as } \\
\text { total output; Multiple samples } \\
\text { may be at each site (i.e., in core). }\end{array}$ \\
\hline Sampler & Sampler type & $\begin{array}{l}\text { Character } \\
\text { Xxxxxxxx.... }\end{array}$ & $\begin{array}{l}\text { Type of } \\
\text { sampling device }\end{array}$ & $\begin{array}{l}\text { As given in source report; } \\
\text { recovery (rcvy) or penetration } \\
\text { ('pen') length appended if given } \\
\text { in source report. For more } \\
\text { complete information on } \\
\text { sampler, see source metadata. }\end{array}$ \\
\hline DataType & Data types & $\begin{array}{l}\text { Character } \\
\mathrm{XXX}: \mathrm{XXX}\end{array}$ & $\begin{array}{l}\text { For audit } \\
\text { principally }\end{array}$ & Source data types (Table A). \\
\hline Gravel & Gravel & Integer 000 & $\begin{array}{l}\text { Gravel grain } \\
\text { size fraction, } \%\end{array}$ & Textural class. \\
\hline Sand & Sand & Integer 000 & $\begin{array}{l}\text { Sand grain size } \\
\text { fraction, } \%\end{array}$ & Textural class. \\
\hline Mud & Mud & Integer 000 & $\begin{array}{l}\text { Mud grain size } \\
\text { fraction, } \%\end{array}$ & Textural class. \\
\hline Clay & Clay & Integer 000 & $\begin{array}{l}\text { Clay grain size } \\
\text { fraction, } \%\end{array}$ & $\begin{array}{l}\text { Textural class; output for '_EXT' } \\
\text { only, as clay value can be } \\
\text { determined only by analysis. }\end{array}$ \\
\hline grain size & grain size & $\begin{array}{l}\text { Decimal } \\
00.00\end{array}$ & $\begin{array}{l}\text { Phi } \\
\text { characteristic } \\
\text { grain size }\end{array}$ & $\begin{array}{l}\text { Consensus of mean and median } \\
\text { grain sizes. }\end{array}$ \\
\hline Sorting & Sorting & Decimal 0.00 & $\begin{array}{l}\text { Phi grain size } \\
\text { dispersion }\end{array}$ & Standard deviation, sorting only. \\
\hline SeafloorClass & Seafloor class & $\begin{array}{l}\text { Character } \\
\text { Xxxxx... }\end{array}$ & $\begin{array}{l}\text { That class (or ' } \\
\text { facies ' ) with }\end{array}$ & Output for '_PRS' table only. \\
\hline
\end{tabular}




\begin{tabular}{|c|c|c|c|c|}
\hline & & & $\begin{array}{l}\text { the maximum } \\
\text { fuzzy } \\
\text { membership, if } \\
\text { above } 30 \%\end{array}$ & \\
\hline ClassMbrshp & $\begin{array}{l}\text { Class } \\
\text { membership }\end{array}$ & Decimal 000 & $\begin{array}{l}\text { Fuzzy } \\
\text { membership (\%) } \\
\text { of the class (or } \\
\text { 'facies'), noted } \\
\text { above }\end{array}$ & Output for '_PRS' table only. \\
\hline $\begin{array}{l}\text { Folk } \\
\text { classification; } \\
\text { Shepard } \\
\text { classification }\end{array}$ & $\begin{array}{l}\text { Folk } \\
\text { classification; } \\
\text { Shepard } \\
\text { classification }\end{array}$ & $\begin{array}{l}\text { Character } \\
\mathrm{xx} . \mathrm{XX} \ldots\end{array}$ & & \\
\hline RockMbrshp & Rock index & Integer 000 & $\begin{array}{l}\text { Fuzzy } \\
\text { membership (\%) }\end{array}$ & $\begin{array}{l}\text { Membership of sample to 'rock } \\
\text { fuzzy set'; reported only in _PRS } \\
\text { data. }\end{array}$ \\
\hline WeedMbrshp & Weed index & Integer 000 & $\begin{array}{l}\text { Fuzzy } \\
\text { membership (\%) }\end{array}$ & $\begin{array}{l}\text { Membership of sample to 'weed } \\
\text { fuzzy set'; reported only in _PRS } \\
\text { data. }\end{array}$ \\
\hline Carbonate & Carbonate & Integer 000 & $\begin{array}{l}\% \text {; may be } \\
\text { Fuzzy } \\
\text { membership } \\
\text { (_PRS). }\end{array}$ & \\
\hline MunsellCode & $\begin{array}{l}\text { Munsell color } \\
\text { code }\end{array}$ & $\begin{array}{l}\text { Character } \\
\text { XXXXX }\end{array}$ & $\begin{array}{l}\text { Standard } \\
\text { alphanumeric } \\
\text { coding of color } \\
\text { partitioned into } \\
\text { Hue, Value, and } \\
\text { Chroma }\end{array}$ & $\begin{array}{l}\text { Ex: '5YR 6/4', See Rock-Color } \\
\text { Chart (Geological Society of } \\
\text { America, 1991). }\end{array}$ \\
\hline OrganicCarbon & $\begin{array}{l}\text { Organic } \\
\text { carbon }\end{array}$ & Integer 000 & $\%$ & $\begin{array}{l}\text { Minimum value from } \\
\text { descriptions (PRS tables) is } \\
0.1 \% \text {. }\end{array}$ \\
\hline ShearStrength & $\begin{array}{l}\text { Log shear } \\
\text { strength }\end{array}$ & Decimal 00.0 & $\begin{array}{l}\text { kiloPascals, } \\
\text { undrained, } \\
\text { unconfined }\end{array}$ & $\begin{array}{l}\text { From a variety of } \\
\text { instrumentation. }\end{array}$ \\
\hline Porosity & Porosity & $\begin{array}{l}\text { Decimal } \\
00.00\end{array}$ & $\%$ & \\
\hline P-waveVelocity & $\begin{array}{l}\text { P-wave } \\
\text { velocity }\end{array}$ & Decimal 00.0 & $\mathrm{~m} / \mathrm{sec}$ & $\begin{array}{l}\text { Usually not corrected for } \mathrm{P} / \mathrm{T} \\
\text { effects. }\end{array}$ \\
\hline $\begin{array}{l}\text { Bottom } \\
\text { roughness }\end{array}$ & Roughness & $\begin{array}{l}\text { Decimal } \\
0000.00\end{array}$ & $\begin{array}{l}\text { Coded to } \\
\text { express the } \\
\text { height and } \\
\text { length of the } \\
\text { bottom feature } \\
\text { with greatest } \\
\text { aspect ratio }\end{array}$ & $\begin{array}{l}\text { In a coding that expresses the } \\
\text { height and length of the bottom } \\
\text { feature with greatest aspect ratio; } \\
\text { a coded output representing the } \\
\text { V:H of the roughness element } \\
\text { with greatest aspect ratio, values } \\
\text { expressed as (rounded) integer } \\
\text { log2. }\end{array}$ \\
\hline $\begin{array}{l}\text { Critical shear } \\
\text { stress }\end{array}$ & $\begin{array}{l}\text { Log critical } \\
\text { shear stress }\end{array}$ & $\begin{array}{l}\text { Decimal } \\
0000.00\end{array}$ & $\begin{array}{l}\log 10 \text { of Tau in } \\
\mathrm{kPa} \text {, }\end{array}$ & $\begin{array}{l}\text { Log } 10 \text { of Tau in } \mathrm{kPa} \text {, being the } \\
\text { shear stress required to initiate } \\
\text { easily observable erosion and }\end{array}$ \\
\hline
\end{tabular}




\begin{tabular}{|c|c|c|c|c|}
\hline & & & & $\begin{array}{l}\text { transport, whether by traction or } \\
\text { suspension; taken from a } \\
\text { compilation of published } \\
\text { relationships ranging from large } \\
\text { boulder to muds, through a range } \\
\text { of grain shapes (eg. shell). }\end{array}$ \\
\hline Sample phase & $\begin{array}{l}\text { Where in } \\
\text { sample the } \\
\text { data are from }\end{array}$ & $\begin{array}{l}\text { Character } \\
\text { Xxxxx..... }\end{array}$ & $\begin{array}{l}\text { Where sample is } \\
\text { from }\end{array}$ & $\begin{array}{l}\text { Records whether the results are } \\
\text { for the whole, bulk sediment, or } \\
\text { just to some special part like: } \\
\text { inside a nodule, burrow-infill, } \\
\text { the sand fraction, porewater } \\
\text { (chemistry), a layer in the core, a } \\
\text { gradient observed in the core, } \\
\text { badly preserved, a layer that is } \\
\text { not properly located, or sample } \\
\text { with questionable location; also } \\
\text { may report a type of analysis or } \\
\text { observation if that is special or } \\
\text { potentially unrepresentative (for } \\
\text { example, XRD, smear slide). } \\
\text { Output is as a word-based } \\
\text { description that may involve } \\
\text { numerics. This field will need to } \\
\text { be selected against when GIS } \\
\text { mappings of the bulk sedient } \\
\text { characters are being mapped. } \\
\text { Only blank entries should be } \\
\text { included in such a mapping. }\end{array}$ \\
\hline
\end{tabular}

Table C. Most frequently occurring biological components that may have textural implications (U.S. waters only)

\begin{tabular}{|l|l|l|l|l|}
\hline \hline barnacles & coralline algae & fish debris_F & pteropods & serpulids \\
\hline bivalves & corals & forams & radiolaria & shells \\
\hline brachiopods & crabs & halimeda & razor clams & sponges_F \\
\hline bryozoa & crustaceans & molluscs & reefs & worm tubes_F \\
\hline calcareous algae & diatoms & nannofossils & scaphopods & \\
\hline clypeasts & echinoids & & & \\
\hline
\end{tabular}

Table D. Components (features*) processed within usSEABED

Only the descriptive terms found in source reports are defined in the dbSEABED thesaurus. Conversely, as usSEABED uses the same thesaurus as its sister data compilations (auSEABED, goSEABED), some terms listed below may not occur within U.S. waters. Only one of possible variations are listed below, for example, laminated (laminae, lamination); mollusc (mollusk, 


\begin{tabular}{|c|c|}
\hline $\begin{array}{l}\text { Major } \\
\text { synonym }\end{array}$ & Triggering words (word variations not included) \\
\hline andest & andesite, augite andesite, benmoreite, trachyandesite \\
\hline anmne_F & anemone, tube anemone, cerinth, cerianthid, coryanactid \\
\hline annld_F & $\begin{array}{l}\text { annelid, arenicola, beachworm, bloodworm, bristleworm, funnelworm, nereid worm, } \\
\text { polychaete, polynoid }\end{array}$ \\
\hline aren_frm & $\begin{array}{l}\text { arenaceous foraminfera, agglutinated foramifera, ammobaculite, ammodiscus, } \\
\text { textularid foraminfera }\end{array}$ \\
\hline artif_F & $\begin{array}{l}\text { artificial, soot, anchor, brass, cinder, coal, contaminated, lumber, obstruction, } \\
\text { petroleum, oil-gas, rubber band, snag, tar, wood chip, wreck }\end{array}$ \\
\hline asterd_F & asteroid, basket star, briseaster, sea star, starfish \\
\hline barit & barite (-concretion -vein) \\
\hline baslt & basalt, diorite, metabasalt, scoria, trap rock, trachybasalt \\
\hline bioturb & bioturbation \\
\hline bitumn & bitumin \\
\hline biv & $\begin{array}{l}\text { bivalve, arctica, astarte, cardium, chama, chione, chlmys, clam (-shell -flat material - } \\
\text { hash -valves), cockle (-anadara -shell), donax, glycymeris, katalysia, lamellibranch, } \\
\text { macoma, mercenaria, mulinia, mussel (-bed -bank -shell), mya, mytilus, nucula, } \\
\text { pelecypod, quahog, rangia, seep mytilid, slipper shells, surf clam, tellina, tellinid, } \\
\text { venerid, venus clams, vesicomyid, yoldia }\end{array}$ \\
\hline bluschst & $\begin{array}{l}\text { blue schist, crossite-albite schist, crossite-quartz schist, glaucophane, quartz crossite } \\
\text { schist, quartz glaucophane schist }\end{array}$ \\
\hline bnth_frm & $\begin{array}{l}\text { benthic foraminfera, archaias, bolivina, bulimina, coralline forams, discorbis, } \\
\text { eponides, homotrema, hyaline, lenticulina, loxostema, miliolid, nodosirid, nonien, } \\
\text { notosirid, peneroplis, porcellanous, rotaiid, uvigerina }\end{array}$ \\
\hline borng_F & boring, bioeroded \\
\hline brach & brachiopod, lingula \\
\hline brncl & barnacle \\
\hline bryz & bryozoa, polyzoa \\
\hline burw_F & burrow, chondrite, clam siphon, crab hole, lebensspurren, Thalassinoides \\
\hline c_alg & calcareous algae, purple algae, red algae \\
\hline calc_ooz & $\begin{array}{l}\text { calcareous ooze, nannofossil -mud -ooze, pteropod -mud -ooze, foraminiferal -marl - } \\
\text { ooze -mud, globigerina -mud -ooze }\end{array}$ \\
\hline calcrst & calcareous crust, tufa \\
\hline calct & calcite (-cement -core -filling -veinlets) \\
\hline carb & allogenic grain, authigenic carbonate, biogenic, calcareous, calcilutite, calcarenite, \\
\hline
\end{tabular}




\begin{tabular}{|c|c|}
\hline & calcirudite, calcareous biogenic, carbonate, limey, marl, skeletal micrite \\
\hline chrcoal_F & charcoal, fire debris \\
\hline chrt & chert, flint, porcellanite \\
\hline claymin & clay mineral, bentonite, chlorite, collophane, illite, kaolinite \\
\hline clypeast & clypeasteriod, sand dollar \\
\hline coal & coal, lignite, bituminous \\
\hline coralgl & algal coral, coralgal \\
\hline crab & crab, hermit crab, sand crab, spider crab, swimming crab \\
\hline crinod_F & crinoid, basket star \\
\hline $\mathrm{crl}$ & $\begin{array}{l}\text { coral, Acropora palmata, brain coral, Dendrophyllia, Madrepore, Manicina, Porite, } \\
\text { sea twig }\end{array}$ \\
\hline crl_dbr & coral debris \\
\hline crlrf & coral reef, coral heads, shingle bank, reefal shoal \\
\hline crnalg & coralline algae, calcareous algae, lithothamnion \\
\hline crustac & crustacea, decapods, lobster, shrimp shell \\
\hline defrmn_F & $\begin{array}{l}\text { deformation, convolute, flame structure, flow structure, load -cast -structure, pull } \\
\text { apart }\end{array}$ \\
\hline diat & diatom, diatomite/diatomaceous \\
\hline dolmt & dolomite, ankerite, molar magnesium carbonate \\
\hline echnd & echinoid, heart urchin, keyhole urchin, sea urchin, spiny urchin \\
\hline echndrm_F & echinoderm \\
\hline fault_F & fault \\
\hline fces & feces, coprolite \\
\hline ferug & $\begin{array}{l}\text { ferruginous, iron fragment, iron (-cement -streak -flake -stain), iron stone, laterite, } \\
\text { limonite }\end{array}$ \\
\hline flasr_bed_F & flaser bed \\
\hline fld & feldspar, albite, andesine, anorthorite, K-feldspar, labradorite, orthoclase, plagioclase \\
\hline frm & calcareous foramifera, foraminifera, globigerina bit, planktonic \\
\hline gas & foamy, gas \\
\hline gbbro & $\begin{array}{l}\text { gabbro, diabase, diorite, dolerite, meta-dolerite, monzodiorite, monzonite, quartz } \\
\text { diorite }\end{array}$ \\
\hline glacl & glacial, diamicton, erratic, moraine, till \\
\hline glauc & glauconite, greensand \\
\hline
\end{tabular}




\begin{tabular}{|c|c|}
\hline gniss & gneiss, diorite gneiss, granite gneiss \\
\hline gradd_F & $\begin{array}{l}\text { coarsening upward, fining upward, increasing grain size, normally graded, reverse } \\
\text { graded }\end{array}$ \\
\hline granit & granite, aplite, granodiorite, pegmatite \\
\hline grnschst & greenschist \\
\hline gstrpd & gastropod, cerithium, conch, turitella, snail, nassarius, olivella, tenebrae, turitella \\
\hline h2s & hydrogen sulfide, hydrogen sulfide -odor -smell, sulfur odor \\
\hline halmda & halimeda, Peyssonnelia \\
\hline holoth & holothurian, sea cucumber \\
\hline hvy_min & $\begin{array}{l}\text { heavy mineral, anatase, andalusite, apatite, black sand, brookite, cassiterite, } \\
\text { clinozoisite, corundum, dumortierite, epidote, garnet, ilmenite, jadeite, kyanite, } \\
\text { leucoxene, magnetite, monazite, ore mineral, piedmontite, rutile, sillimanite, sphene, } \\
\text { spinel, staurolite, titanomagnetite, titanite, tourmaline, topaz, zircon, zoisite }\end{array}$ \\
\hline hydrt & hydrate, gas hydrate \\
\hline ign_rck & $\begin{array}{l}\text { igneous rock, acidic rock, alkali basinite, augite plagioclase porphyry, augite } \\
\text { porphyry, basic rock, dacite, felsite, olivine plagioclase clinopyroxene, olivine } \\
\text { plagioclase phyric, plagioclase andesite porphyry, plagioclase augite porphyry, } \\
\text { plagioclase porphyry, plutonic rock, porphyry, rhyolite, syenite, trachyte }\end{array}$ \\
\hline klp_F & kelp, brown algae, ecklonia, M. vertebralis, red brown algae \\
\hline lamintd_F & laminated \\
\hline lenticlr_bed & lenticular bed, lenticular mass \\
\hline limstn & $\begin{array}{l}\text { limestone, beach rock, bioclastic -floatstone -grainstone -limestone -rudstone, } \\
\text { boundstone, bryozoan -floatstone -grainstone -rudstone, calcareous -chip -rubble - } \\
\text { rock, coral limestone, floatstone, grainstone, packstone, rudstone, wackestone }\end{array}$ \\
\hline lmp_F & lump, aggregate, ball, cast, clump, compact clot, intraclast, pellet, pisolitic, peloid \\
\hline lrg_frm & $\begin{array}{l}\text { large foram, foraminferal gravel, amphistegina, heterostegina, macro foraminifera, } \\
\text { marginopora }\end{array}$ \\
\hline maf & $\begin{array}{l}\text { mafic, actinolite, aegirite, amphibole, augite, (brown- green- basaltic-) hornblende, } \\
\text { bronzite, clinopyroxene, ferromagnesian, hypersthene, olivine, orthopyroxene, } \\
\text { oxyhornblende, pyroxene, titanaugite, titaniferous, tremolite }\end{array}$ \\
\hline met & metamorphic, calcsilicate, granitized, mylonite, porphyroblast, saussurite \\
\hline methne & methane \\
\hline metlif & metalliferous \\
\hline mica & mica, biotite, chlorite, muscovite, sericite, talc \\
\hline mlsc & mollusc \\
\hline mn_crst & $\begin{array}{l}\text { manganese crust, manganese iron oxide crust, manganese nodule, manganese } \\
\text { pavement, manganese phosphate material }\end{array}$ \\
\hline
\end{tabular}




\begin{tabular}{|c|c|}
\hline mn_nod & manganese nodule, iron manganese nodule, manganese concretion, micronodule \\
\hline mnoxd & manganese oxide, iron-manganese (-coat -stain -veneer), iron-manganese oxide \\
\hline motl_F & mottle, chickwire mottle \\
\hline mudlmp_F & $\begin{array}{l}\text { mud lump, armored mud ball, silty lump, clay (-aggregate -ball -chip -clast -gall - } \\
\text { lump -mass -pod), mud (-aggregate -ball -chunk -clump -clot -clast -lump -pebble - } \\
\text { pellet, claystone -chip -gall), sandstone fragment, soft pebble, shale (-fragment - } \\
\text { concretion) }\end{array}$ \\
\hline mudstn & $\begin{array}{l}\text { mudstone, calcareous (-mudstone- siltstone), clay (-rock -shale -stone), marlstone, } \\
\text { mud (-rock -stone), pelite, shale, siliceous shale, siltstone }\end{array}$ \\
\hline nan & nannofossil coccolith, nannofossil (-coccolith -ooze), silicoflagellate \\
\hline nod_F & nodule, concretion \\
\hline odr & odor, anoxic, fetid, foul, fishy, organic, sewage, smell \\
\hline oil & oil, oil glob, oil sheen \\
\hline ool & oolite, sporbo \\
\hline $\mathrm{OOZ}$ & ooze \\
\hline ophiurd_F & ophiuroid, brittle star, ophiomusium \\
\hline orgcbn & $\begin{array}{l}\text { organic carbon, carbonaceous, organic (-streak -detritus -matter -mud -content - } \\
\text { enriched -material -part -paricle -rich -rimmed), sapropel }\end{array}$ \\
\hline oyst & oyster, jingle shell \\
\hline peat & peat, lignite \\
\hline pelag & pelagic, hemipelagic, planktic, planktonic \\
\hline phspht & phosphate, phosphorite \\
\hline pit_F & pit, crater, feeding depression, hole, pockmark, mound, resting trace \\
\hline planr_bed_F & planar bed \\
\hline plnk_frm & planktonic foramifera, globerina, globorotalid, planktic foraminfera \\
\hline plnt_F & plant, mangrove, root, vegetation, weed, root \\
\hline ptr & pteropod \\
\hline pumc & pumice, ash \\
\hline pyrt & pyrite, marcasite \\
\hline qtz & $\begin{array}{l}\text { quartz, arkosic sand, calcareous quartz sand, milky vein quartz, quartz (-content - } \\
\text { fragment -grain -granule -groundmass -mass -rich -vein -veinlet -crystal), quartzose, } \\
\text { quartzite (-cobble -gravel -pebble), sandstone (-chunk -fragment), silica }\end{array}$ \\
\hline $\mathrm{rad}$ & radiolaria \\
\hline ripl & ripple, bedform \\
\hline rlct_F & relict \\
\hline
\end{tabular}




\begin{tabular}{|c|c|}
\hline root_struct & root structure, root clast, root trace \\
\hline rzr_clm & razor clam, ensis, pinna, pteria, pelecypod \\
\hline schst & $\begin{array}{l}\text { schist, -albite -chlorite -epidote, -albite -chlorite, -albite -mica, -albite -quartz - } \\
\text { chlorite, -biotite -quartz, -chlorite -albite, -chlorite -quartz -albite, -chlorite, - } \\
\text { phyllitic, -quartz -albite, -quartz -albite -chlorite, -quartz -biotite, -quartz -chlorite }\end{array}$ \\
\hline scllp & scallop, astropecten, pecten, placopecten \\
\hline scour & scour, crag and tail, erosional, lag deposit \\
\hline scphpd & scaphopod, dentalium \\
\hline seagrs_F & $\begin{array}{l}\text { seagrass, acetabularia, amphibolis, batophora, eel grass, grass, halophila, } \\
\text { heterozostera, phyllospadix, posidonia, sargassum, strap grass, syringodium, } \\
\text { manatee grass, thallassia, zostera }\end{array}$ \\
\hline sft_alg_F & $\begin{array}{l}\text { soft algae, algal (-scum -filament -mush -strand), Bossea, green algae, macrophytic, } \\
\text { red algae }\end{array}$ \\
\hline sftcrl_F & soft coral, alcynacian, ascidian, coelentrate, gorgonian, hydrozoa \\
\hline shl & shell, shell (-bed -bank -carpet -fraction -content -material), shellfish, valves \\
\hline shl_dbr & $\begin{array}{l}\text { shell debris, shell hash, coquina, shell (-bit -conglomerate -fragments -festoon -grit - } \\
\text { lag -mash -material -piece -particle) }\end{array}$ \\
\hline shrmp_F & shrimp, amphipod, ampelisca, copepod, isopod, tanid \\
\hline sidrt & siderite, siderite nodule \\
\hline sil_ooz & siliceous ooze, siliceous mud \\
\hline slte & slate, phyllite, quartzite, metamorphic rock \\
\hline sndstn & sandstone, gritstone, graywacke, labile sandstone, sandstone reef, wacke \\
\hline sol_crl & solitary coral, cup coral, disc coral, horn coral, lophelia coral \\
\hline spng_F & $\begin{array}{l}\text { sponge, calcareous sponge, glass sponge, hard sponge, hexactinellid sponge, } \\
\text { porifera, Thalassodendron sponge }\end{array}$ \\
\hline spoil_F & spoil, brick, coke, dumped sediment \\
\hline srpul & serpulid, serpulid tube, serpulid worm tube \\
\hline sulf & sulfide, chalcopyrite \\
\hline trail_F & trail, trace (animal), track \\
\hline $\operatorname{trrg}$ & terrigenous, lithic, inorganic \\
\hline umafic & $\begin{array}{l}\text { ultramafic, amphibolite, anorthosite, dunite, greenstone, harzburgite, lherzolite, } \\
\text { norite, orthopyroxenite, periodotite, picrite, pyroxenite, serpentinite, troctolite, } \\
\text { wehrlite }\end{array}$ \\
\hline vol_rck & volcanic rock, volcanic (-cobble -pebble) \\
\hline volgls & volcanic glass, obsidian, hyaloclastite, pyroclastic, quenched, vitric, subvitreous \\
\hline volrck & volcanic rock, welded tuff \\
\hline
\end{tabular}




\begin{tabular}{|l|l|}
\hline volsed & volcanic sediment, ash, tuff, lapilli \\
\hline wood & wood, bark, twig \\
\hline wrm_F & $\begin{array}{l}\text { worm, chordate, echiurid, fan -flat (-glob -juicy -long -sand -tube worm), maldanid, } \\
\text { pogonophora, priapulida, sliverfish, siphunculid, tunicate }\end{array}$ \\
\hline wrm_tbe_F & $\begin{array}{l}\text { worm tube, agglutinated worm tube, amphipod tube, annelid worm tube, arenicola, } \\
\text { chitinous worm tube, diopatra worm tube, polychaete worm tube, pogonophoran } \\
\text { tube worm, vestimentiform tube worm }\end{array}$ \\
\hline wavy_bed_F & wavy bed \\
\hline
\end{tabular}

\section{Table E. Facies and their component makeup}

Facies values are determined by a combination of components and their mined values from wordbased descriptions. Numeric textural, geochemical, and geophysical information held in _PRS data files. Values represent memberships to fuzzy sets, given as percents. A minimum of $30 \%$ component presence is required to trip a given facies, and a component may trip more than one facies. See_FAC files for actual data, and table $\mathrm{C}$ for component information. Facies notes presence only, not absence.

\begin{tabular}{|l|l|l|l|}
\hline \hline \multicolumn{1}{|c|}{ Field name } & \multicolumn{1}{|c|}{ Parameter } & $\begin{array}{l}\text { Data format, } \\
\text { units }\end{array}$ & \multicolumn{1}{|c|}{ Information/triggering components } \\
\hline Latitude* & Latitude & $\begin{array}{l}\text { Decimal } \\
00.00000\end{array}$ & Decimal degrees, $90^{\circ}$ to $-90^{\circ}$ range \\
\hline Longitude* & Longitude & $\begin{array}{l}\text { Decimal } \\
000.00000\end{array}$ & Decimal degrees, $-180^{\circ}$ to $180^{\circ}$ range \\
\hline WaterDepth* & Water depth & $\begin{array}{l}\text { Integer } \\
00000\end{array}$ & Meters \\
\hline SampleTop* & Sample top & $\begin{array}{l}\text { Decimal } \\
000.00\end{array}$ & Meters below seabed surface \\
\hline SampleBase* & Sample base & $\begin{array}{l}\text { Decimal } \\
000.00\end{array}$ & Meters below seabed surface \\
\hline SiteName* & Site name & $\begin{array}{l}\text { Character } \\
\text { XXX: XXX }\end{array}$ & Survey or laboratory code for the sampling site \\
\hline DataSetKey* & $\begin{array}{l}\text { Dataset number } \\
\text { key }\end{array}$ & Integer 000 & $\begin{array}{l}\text { Relational key to_SRC file;_SRC file contains } \\
\text { links to source metadata }\end{array}$ \\
\hline SiteKey* & Site number key & $\begin{array}{l}\text { Integer } \\
0000000\end{array}$ & $\begin{array}{l}\text { Relational key to other data files. Each site } \\
\text { counted sequentially as total output; core data } \\
\text { may have more than one sample per site. }\end{array}$ \\
\hline Terrigenous & Terrigenous & $(\%)$ & $\begin{array}{l}\text { Relational key to other data files. Each site } \\
\text { counted sequentially as total output; Multiple } \\
\text { samples may be at each site (i.e., in core). }\end{array}$ \\
\hline SampleKey* & $\begin{array}{l}\text { Sample number } \\
\text { key }\end{array}$ & $\begin{array}{l}\text { Integer } \\
0000000\end{array}$ \\
\hline
\end{tabular}




\begin{tabular}{|l|l|l|l|}
\hline Carbonate & Carbonate & $(\%)$ & Calcrst, calct, carb, dolmt, limstn, sidrt \\
\hline Igneous & Igneous & $(\%)$ & Andest, baslt, gbbro, granit, ign_rck, umafic \\
\hline Volcanic & Volcanic & $(\%)$ & Baslt, pumc, vol_rck, volgls, volrck, volsed \\
\hline Metamorphic & Metamorphic & $(\%)$ & Bluschst, gniss, grnschst, met, schst, slte \\
\hline Mineralized & Mineralized & $(\%)$ & Barit, metlif, phspht, pyrt, sulf \\
\hline AuthFeMn & $\begin{array}{l}\text { Authigenic Fe } \\
\text { Mn }\end{array}$ & $(\%)$ & Mn_crust, mn_nod, mnoxd, ferug \\
\hline Ooze & Ooze & $(\%)$ & Ooz, calc_ooz, sil_ooz \\
\hline Carbon & Carbon & $(\%)$ & Coal, bitumn, orgcbn, peat \\
\hline GeochemSignal & $\begin{array}{l}\text { Geochemical } \\
\text { signal }\end{array}$ & $(\%)$ & Gas, h2s, hydrt, methne, odr, oil \\
\hline Forams & Forams & $(\%)$ & Aren_frm, bnth_frm, frm, lrg_frm, plnk_frm \\
\hline OtherCalcPelag & $\begin{array}{l}\text { Other } \\
\text { calcareous } \\
\text { pelagics }\end{array}$ & $(\%)$ & Nan, ptr, calc_ooz \\
\hline SilcPelag & $\begin{array}{l}\text { Siliceous } \\
\text { pelagics }\end{array}$ & $(\%)$ & Diat, rad, sil_ooz \\
\hline Shell & Shell & $(\%)$ & Shl, shl_dbr \\
\hline Coral & Coral & $(\%)$ & Crl, crl_dbr, crlrf, sol_crl \\
\hline HardPlant & Hard plants & $(\%)$ & C_alg, coralgl, crnalg, halmda \\
\hline
\end{tabular}

\section{Data Catalog}

Data provided in this publication include geographic coordinates to allow for integration into a Geographic Information System (GIS). A GIS is defined as a system of hardware and software to support the display, manipulation, and analysis of spatial data for mapping and complex data solving. This integrated package provides researchers the ability to integrate, analyze, and map the various data sets as an aid to scientific research, and policy-making decisions tied to the environment.

The five individual sediment/seafloor data layers along with additional basemap data layers have been compiled into an ArcView TM project file (la.apr) that is located at the top-level directory of this publication. The project file is intended to be opened and the data viewed with the Environmental Systems Research Institute, Inc. (ESRI) ArcView ${ }^{\mathrm{TM}}$ or ArcGIS ${ }^{\mathrm{TM}}$ software. The project file has been modified to reflect relative paths to the archived data as organized for this publication. To open the supplied project file and view the datasets, the user must start the appropriate software, navigate to the top-level of this publication and open the project file (la.apr).

For those who do not have the ESRI software or a compatible GIS data browser available on their computer, a free viewer, ArcExplorer ${ }^{\mathrm{TM}}$, is available from ESRI. Please note that the ArcExplorer ${ }^{\mathrm{TM}}$ software is limited to the Microsoft Windows operating system. 
Each GIS data layer from this publication is cataloged in the table below for easy access. The individual data layers are described and include the shapefile name (e.g. _EXT is extracted data ) which is linked to a browse graphic showing the data layer extent and coverage.

Federal Geographic Data Committee (FGDC) metadata for the individual data layers is provided in three versions (HTML, FAQ, and text). Selecting associated metadata files from the table below will open the information in a new browser window.

A 'zip' compressed, downloadable archive file containing the ArcView ${ }^{\mathrm{TM}}$ shapefile for each data layer is also provided. Compressed downloadable files were created using the Windows program WINZIP v8.0. For those users who do not have software capable of uncompressing the archived zip files, they may obtain a free version of the software from Winzip Computing, Inc. or Pkware, Inc. In addition to the ArcView ${ }^{\mathrm{TM}}$ shapefile, the sediment data layers are available in an ASCII text format and a Microsoft Excel spreadsheet format to allow users who may not have access to GIS software to read the shapefile and examine the datasets. The first record of the ASCII file and Excel spreadsheet contains the name of the data fields for that file.

\section{USSEABED DATA}

\section{DIRECTORY: data/usSEABED}

\begin{tabular}{|c|c|c|}
\hline $\begin{array}{l}\text { Data Layer Name } \\
\text { and Description }\end{array}$ & Metadata & Files \\
\hline $\begin{array}{l}\text { LA_PRS - usSEABED parsed (word-based) data for the } \\
\text { Louisiana region. An explanation of the individual data sets may } \\
\text { be found in the Data Dictionary section. }\end{array}$ & $\begin{array}{l}\text { HTML } \\
\text { FAQ } \\
\text { text }\end{array}$ & $\begin{array}{l}\text { zip } \\
\text { Excel } \\
\text { text }\end{array}$ \\
\hline $\begin{array}{l}\text { LA_EXT - usSEABED extracted data for the Louisiana region . } \\
\text { An explanation of the individual data sets may be found in the } \\
\text { Data Dictionary section. }\end{array}$ & $\begin{array}{l}\text { HTML } \\
\text { FAQ } \\
\text { text }\end{array}$ & $\begin{array}{l}\text { zip } \\
\text { Excel } \\
\text { text }\end{array}$ \\
\hline $\begin{array}{l}\text { LA_CLC - usSEABED calculated data for the Louisiana region. } \\
\text { An explanation of the individual data sets may be found in the } \\
\text { Data Dictionary section. }\end{array}$ & $\begin{array}{l}\text { HTML } \\
\text { FAQ } \\
\text { text }\end{array}$ & $\begin{array}{l}\text { zip } \\
\text { Excel } \\
\text { text }\end{array}$ \\
\hline $\begin{array}{l}\text { LA_FAC - usSEABED facies data for the Louisiana region. An } \\
\text { explanation of the individual data sets may be found in the Data } \\
\text { Dictionary section. }\end{array}$ & $\begin{array}{l}\text { HTML } \\
\text { FAQ } \\
\text { text }\end{array}$ & $\begin{array}{l}\text { zip } \\
\text { Excel } \\
\text { text }\end{array}$ \\
\hline $\begin{array}{l}\text { LA_CMP - usSEABED component data for the Louisiana } \\
\text { region. An explanation of the individual data sets may be found } \\
\text { in the Data Dictionary section. }\end{array}$ & $\begin{array}{l}\text { HTML } \\
\text { FAQ } \\
\text { text }\end{array}$ & $\begin{array}{l}\text { zip } \\
\text { Excel } \\
\text { text }\end{array}$ \\
\hline $\begin{array}{l}\text { GMX SRC - usSEABED source data for the Gulf Coast. An } \\
\text { explanation of the individual data sets may be found in the Data } \\
\text { Dictionary section. }\end{array}$ & $\begin{array}{l}\text { Online } \\
\text { text }\end{array}$ & $\begin{array}{l}\text { Online } \\
\text { html }\end{array}$ \\
\hline
\end{tabular}

\section{BATHYMETRY}

DIRECTORY: data/bathymetry 
gmx_grd8bit.sid - Coastal Relief Model Bathymetry for the Gulf of Mexico.
HTML

FAQ zip

text 


\section{BASEMAPS}

DIRECTORY: data/basemaps

\begin{tabular}{|c|c|c|}
\hline $\begin{array}{l}\text { Data Layer Name } \\
\text { and Description }\end{array}$ & Metadata & Files \\
\hline $\begin{array}{l}\text { eez - Boundaries of the U.S. Exclusive Economic Zone (US } \\
\text { EEZ) of the Louisiana project area, extending } 200 \text { nautical miles } \\
\text { offshore. }\end{array}$ & $\begin{array}{l}\text { HTML } \\
\text { FAQ } \\
\text { text }\end{array}$ & zip \\
\hline $\begin{array}{l}\text { Federal Boundary - The } 9 \text { nautical mile boundary between } \\
\text { state and federal waters off Louisiana. }\end{array}$ & $\begin{array}{l}\text { HTML } \\
\text { FAQ } \\
\text { text }\end{array}$ & zip \\
\hline state_bounds - Internal US state boundaries & $\begin{array}{l}\text { HTML } \\
\text { FAQ } \\
\text { text }\end{array}$ & zip \\
\hline nos80k - US states map & $\begin{array}{l}\text { HTML } \\
\text { FAQ } \\
\text { text }\end{array}$ & zip \\
\hline
\end{tabular}

\section{COASTAL CHANGE ATLAS}

DIRECTORY: online

\begin{tabular}{c|l|l|}
$\begin{array}{c}\text { Data Layer Name } \\
\text { and Description }\end{array}$ & \multicolumn{1}{c|}{ Metadata } & \multicolumn{1}{c}{ Files } \\
\hline coastal change - USGS Digital Data Series 79 & online & online \\
\hline
\end{tabular}

Google Earth KML files 


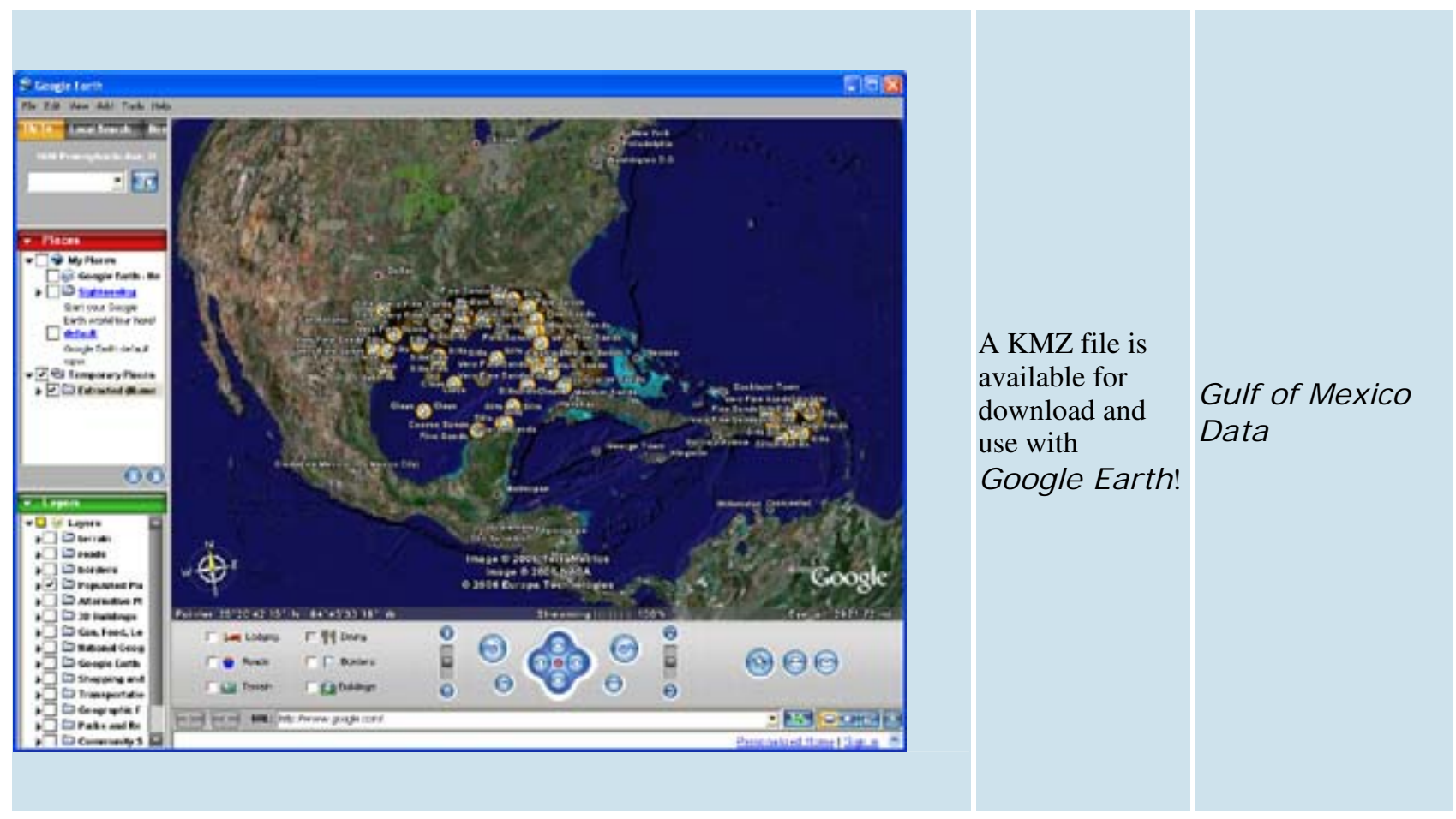

\section{Browse Maps}

\section{Overview}

The images and maps in this Open-File Report serve as examples of products that may be generated using the usSEABED data provided in the Data Catalog section. A wide array of additional gridded maps and plots of sea floor sediment texture, character, and related geologic attributes from the Louisiana offshore region can be constructed from the usSEABED data using various Geographic Information Systems (GIS) applications (e.g. ArcView ${ }^{\mathrm{TM}}$, ArcExplorer ${ }^{\mathrm{TM}}$, MapInfo $\left.{ }^{\mathrm{TM}}\right)$. Several examples are shown below, but the data are in no way limited to these few displays.

For this section of the publication, we have chosen to focus on Extracted and Parsed data within the usSEABED collection. Extracted data: those data from strictly performed, lab-based, numeric analyses. The _EXT file is based on rigorous lab-determined values and forms the most reliable data sets. Numeric data obtained from verbal logs from core descriptions, shipboard notes, and (or) photographic descriptions are held in the parsed data set (_PRS). The input data are maintained using the terms employed by the original researchers and are coded using phonetically sensible terms for easier processing by dbSEABED. For expanded definition of these data sets, please consult the Data Dictionary section of this publication. 


\section{References Cited}

\section{Selected \& Cited References}

The following references contain basic textural data, discuss sea-floor sediment distribution, or relate to sediment classification schemes in the Louisiana offshore region. Some of the references appear in the preceding text, while others are included to make readers aware of available information.

Autin, W.J.; Burnes, S.F.; Miller, B.J.; Saucier, R.T., and Snead, J.I. 1991. Quaternary geology of the Lower Mississippi Valley. In : Morrison, R.B. (ed.). Quaternary nonglacial geology; conterminous United States . Geological Society of America. K-2: 547-582.

Barras, J.A., Bourgeois, P.E., and Handley, L.R., 1994, Land loss in coastal Louisiana 1956-90: National Biological Survey, National Wetlands Research Center Open-File Report 94-01, 10 color plates.

Boyd, R.; Suter, J.R., and Penland, S. 1989 . Relation of sequence stratigraphy to modern sedimentary environments. Geology. 17: 926-929.

Brooks, G.R.; Kindinger, J.; Penland, S.; Williams S.J., and McBride, R.A. 1995. East Louisiana continental shelf sediments: a product of delta reworking. Journal of Coastal Research. 11(4): 1026-1036.

Buczkowski, B.J., Reid, J.A., Jenkins, C.J., Reid, J.M., Williams, S.J., and Flocks, J.G., 2006, usSEABED: Gulf of Mexico and Carribbean (Puerto Rico and U.S. Virgin Islands) Offshore Surficial Sediment Data Release: U.S. Geological Survey Data Series 146, Version 1.0, CDROM. ONLINE

Buffler, R.T. and Thomas, W.A. 1994. Crustal structure and evolution of the southeastern margin of North America and the Gulf of Mexico basin. In: Speed, R.C. (ed.), Phanerozoic evolution of North American continent-ocean transitions . Geological Society of America. CTV-1: 219-264. Byrne, J.V.; LeRoy, D.O., and Riley, C.M. 1959. The chenier plain and its stratigraphy, southwestern Louisiana. Gulf Coast Association of Geological Societies Transactions . 9: 261270.

Coleman, J.M. and Gagliano, S.M. 1964. Cyclic sedimentation in the Mississippi River deltaic plain . Gulf Coast Association of Geological Societies Transactions . 14: 67-80.

Coleman, J.M. and Prior, D.B. 1980. Deltaic sand bodies. American Association of Petroleum Geologists Continuing Education Course.American Association of Petroleum Geologists: 171p. Coleman, J.M. 1981. Deltas: Processes of Deposition and Models for Exploration. Burgess: 124p.

Coleman, J.M.; Prior, D.B., and Lindsay, J.F. 1983. Deltaic influences on shelf edge instability processes. In : Stanley, D.J. and Moore, G.T. (eds.), The shelfbreak; critical interface on continental margins. Society of Economic Paleontologists and Mineralogists: 121-137.

Coleman, J.M. 1988. Dynamic changes and processes in the Mississippi River delta. Geological Society of America Bulletin . 100: 999-1015.

Coleman, J.M.; Roberts, H.H., and Bryant, W.R., 1991. Late Quaternary sedimentation. In : Salvador, A. (ed.), The Gulf of Mexico Basin .Geological Society of America : 325-352.

Coleman, J.M.; Roberts H.H., and Stone, G.W. 1998. Mississippi River delta: an overview. Journal of Coastal Research. 14(3): 698-716.

Curray, J.R. 1960. Sediments and history of Holocene transgression, continental shelf, northwest Gulf of Mexico. In : Shepard, F.P.; Phleger F.B., and Van Andel, T.H. (eds.), Recent Sediments, Northwestern Gulf of Mexico . American Association of Petroleum Geologists: 221-236. 
Fairbanks, R.G. 1989. A 17,000-year glacio-eustatic sea level record: influence of glacial melting rates on the Younger Dryas event and deep-ocean circulation. Nature , 342: 637-642.

Fisk, H.N. 1944. Geologic investigations of the alluvial valley of the lower Mississippi River . Vicksburg, Mississippi : U. S. Army Corp of Engineers, Mississippi River Commission: 78p.

Fisk, H.N.; Kolb, C.R.; McFarlan, E. J r., and Wilbert, L.J. Jr. 1954. Sedimentary framework of the modern Mississippi delta [ Louisiana ]. Journal of Sedimentary Petrology, 24: 76-99.

Fisk, H.N. and McFarlan, E. Jr. 1955. Late Quaternary deltaic deposits of the Mississippi River. Geological Society of America Special Paper . 62: 279-302.

Fisk, H.N. 1955. Sand facies of recent Mississippi delta deposits. Proceedings of the 4th World Petroleum Congress, Section 1 ( Rome, Italy ). John Wiley \& Sons. Chichester, International: 377-398.

Fisk, H.N. and McClelland, B. 1959. Geology of continental shelf off Louisiana : its influence on offshore foundation design. Geological Society of America Bulletin. 70: 1360-1394.

Fisk, H.N. 1961. Bar-finger sands of the Mississippi delta. In: Geometry of sandstone bodies . Proceedings of the symposium at the 45th annual meeting of the American Association of Petroleum Geologists: 29-52.

FitzGerald, D., Kulp, M.A., Penland, S., Flocks, J., and Kindinger, J. 2004. Morphologic and stratigraphic evolution of muddy ebb-tidal deltas along a subsiding coast: Barataria Bay, Mississippi River delta. Sedimentology . 51 (6): 1157-1178.

Flocks, J.G., Ferina, N.F., Dreher, C., Kindinger, J.L., Fitz Gerald, D.M., and Kulp, M.A. 2006. High-resolution stratigraphy of a Mississippi subdelta-lobe progradation in the Barataria Bight, north-central Gulf of Mexico. Journal of Sedimentary Research . v 76: 429-443.

Folk, R.L., 1954. The distinction between grain size and mineral composition in sedimentary rock nomenclature. Journal of Geology 62 (4), 344-359.

Folk, R.L., 1974, The petrology of sedimentary rocks: Austin, Tex., Hemphill Publishing Co., 182 p.

Frazier, D.E. 1967. Recent deltaic deposits of the Mississippi River : their development and chronology. Gulf Coast Association of Geological Societies Transactions . 27: 287-315.

Frazier, D.E. 1974. Depositional episodes: Their relationship to the Quaternary stratigraphic framework in the northwestern portion of the Gulf basin.Texas Bureau of Economic Geology. Circular 74-1: 28p.

Galloway, W.E.; Bebout, D.G.; Fisher, W.L.; Dunlap, J.B., Cabrera - Castro, R., Lugo - Rivera, J.E., and Scott, T.M. 1991. Cenozoic. In : Salvador, A. (ed.). The Gulf of Mexico Basin . Geological Society of America : 245-324.

Gould, H.R. and McFarlan, E. Jr. 1959. Geologic history of the chenier plain, south-western Louisiana. Gulf Coast Association of Geological Societies Transactions. 9: 261-270.

Kindinger, J.; Penland, S.; Williams, S.J., and Suter, J.R. 1989. Inner shelf deposits of the Louisiana-Mississippi-Alabama region, Gulf of Mexico. Gulf Coast Association of Geological Societies Transactions. 39: 413-420.

Kindinger, J.L., Penland, S., Williams. S.J_, Brooks, G.R., Suter, J.R., and McBride, R.A.. 1991. Late Quaternary geologic framework, north-central Gulf of Mexico. in N.C. Kraus, K.C. Gingrich, and D.L. Kriebel, (eds.). Coastal Sediments ' 91 . American Society of Civil Engineers. v 1: 1096-1110.

Kolb, C.R. and Van Lopik, J.R. 1966. Depositional environments of the Mississippi River deltaic plain, southeastern Louisiana. In : Shirley, M.L. and Ragsdale, J.A. (eds.), Deltas . Texas Geological Society: 17-62.

Krawiec, W. 1966. Recent sediments of the Louisiana inner continental shelf. Rice University. Doctoral thesis: $139 p$. 
Kulp, M.A.; Howell, P.; Adiau, S.; Penland, S.; Kindinger, J.L., and Williams, S.J. 2002. Latest Quaternary stratigraphic framework of the Mississippi River delta region. Gulf Coast Association of Geological Societies Transactions . 52: 573-82.

Kulp, M., Penland, S., Williams, S. J., Jenkins, C., Flocks, J., and Kindinger, J. 2005. Geological framework, evolution, and sediment resources for restoration of the Louisiana coastal zone, Journal Coastal Research, Special Issue No. 44: 56- 71.

List, J., Jaffe, B.E., Sallenger, A.J. Jr., Williams, S.J., McBride, R.A., Penland, S., Hopkins, D., and Wilson, J.O., Jr. 1994. Louisiana barrier island erosion study, atlas of sea-floor changes from 1878 to 1989. U.S. Geological Survey Miscellaneous Investigations I-2150-B: 81 p.

Ludwick, J.C. 1964. Sediments in northeastern Gulf of Mexico. In : Papers in marine geology Shepard Commemorative Volume. New York : Macmillan: 204-238.

Mann, J.C. and Thomas, W.A. 1968. The ancient Mississippi River. Gulf Coast Association of Geological Societies Transactions. 18: 187-204.

McFarlan, E. Jr. 1961. Radiocarbon dating of late Quaternary deposits, south Louisiana. Geological Society of America Bulletin. 72: 129-157.

McFarlan, E. Jr. and LeRoy, D.O. 1988. Subsurface geology of the late Tertiary and Quaternary deposits, coastal Louisiana and the adjacent continental shelf. Gulf Coast Association of Geological Societies Transactions . 38: 421-433.

Penland, S. and Boyd, R. 1981. Shoreline changes on the Louisiana barrier coast. Oceans '81 . 209229.

Penland, S.; Boyd, R., and Suter, J.R. 1988. Transgressive depositional systems of the Mississippi delta plain: a model for barrier shoreline and shelf sand development. Journal of Sedimentary Petrology . 58(6): 932-949.

Penland, S. and Suter, J.R. 1983. Transgressive coastal facies preserved in barrier island arc retreat paths in the Mississippi River delta plain. Gulf Coast Association of Geological Societies Transactions . 33: 367-382.

Penland, S. and Suter, J.R. 1988. Nearshore sand resources in the Eastern Isles Dernieres Barrier Island Arc . Baton Rouge, Louisiana. Louisiana Geological Survey. Open File Series 88-08: 14p.

Penland, S. and Suter, J.R. 1989. The geomorphology of the Mississippi River Chenier plain. Marine Geology. 90: 231-258.

Penland, S.; Suter, J.R.; McBride, R.A.; Williams, S.J.; Kindinger, J.L., and Boyd, R. 1989. Holocene sand shoals offshore of the Mississippi River delta plain. Gulf Coast Association of Geological Societies Transactions . 39: 471-480.

Penland, S.; Suter, J.R.; Ramsey, K.; McBride, R.A.; Williams, S.J., and Groat, C.G. 1990. Offshore sand resources for coastal erosion control in Louisiana. Gulf Coast Association of Geological Societies Transactions . 40: 721-731.

Penland, S., McBride, R.A., Williams, S.J., Boyd, R., and Suter, J.R. 1991. Effects of sea level rise on the Mississippi River delta plain, in N.C. Kraus, K.C. Gingrich, and D.L. Kriebel (eds.). Coastal Sediments '91 : American Society of Civil Engineers. v 2: 1248-1264.

Penland, S., Wayne, L., Britsch, D., Williams, S.J., Beall, A., and Butterworth, V. 2000a. Geomorphic classification of coastal land loss between 1932 and 1990 in the Mississippi River delta plain, southeastern, Louisiana, USGS Open-File Report 00-417.

Penland, S., Wayne, L., Britsch, D., Williams, S.J., Beall, A., and Butterworth, V. 2000b. Process classification of coastal land loss between 1932 and 1990 in the Mississippi River delta plain, southeastern, Louisiana. USGS Open-File Report 00-418.

Penland, Shea, Beall, Andrew, and Waters, Jeff, editors, 2001, Environmental atlas of the Lake Pontchartrain Basin, Lake Pontchartrain Basin Foundation, New Orleans, LA, 185 p. online see 
also: Penland, Shea, Beall, Andrew, and Kindinger, Jack, 2002, Environmental atlas of the Lake Pontchartrain Basin: U.S. Geological Survey Open-File Report 02-206, online

Penland, S., Britsch, L. D., Beall, A., and Williams, S. J. 2002. A coastal land loss classification for the Mississippi River delta plain. Gulf Coast Association Geological Societies Transactions. v 52. Penland, S., Connor, P.F., Beall, A., Fearnley, S., and Williams, S.J. 2005. Changes in Louisiana 's shoreline: 1855-2002. Journal of Coastal Research . Special Issue no. 44: 7-39.

Poppe, L.J., and Polloni, C.F. (eds.), 2000, USGS East-Coast Sediment Analysis: Procedures, Database, and Georeferenced Displays, U.S. Geological Survey Open-File Report 00-358, CDROM. ONLINE

Poppe, L.J., Williams, S.J., and Paskevich, V.F., Editors, (2005). "USGS East-coast sediment analysis: procedures, database, and GIS data", U.S. Geological Survey Open-File Report 20051001, DVD-ROM. ONLINE

Reid, J.A., Reid, J.M., Jenkins, C.J., Zimmermann, M., Williams, S.J., and Field, M.E., 2006, usSEABED: Pacific Coast (California, Oregon, Washington) Offshore Surficial-Sediment Data Release: U.S. Geological Survey Data Series 182, version 1.0. ONLINE

Reid, J.M., Reid, J.A., Jenkins, C.J., Hastings, M.E., Williams, S.J., and Poppe, L.J. 2005. "usSEABED: Atlantic coast offshore surficial sediment data release", U.S. Geological Survey Data Series 118, Version 1.0, CD-ROM. ONLINE

Roberts, H.H.. 1997. Dynamic change of the Holocene Mississippi River delta plain: the delta cycle . Journal of Coastal Research. 13(3): 605-627.

Rubec, P.J., J. Lewis, D. Reed, C.F. Ashbaugh, C. Lashley, S. Versaggi, R.H. Weisberg, L. Zheng, R. He, and C. Jenkins. 2005. Refinement of An Electronic Logbook To Support Fishing Operations By Predicting Abundance In Relation To Environmental Conditions Off The West Coast Of Florida. Report by Florida Fish \& Wildlife Conservation Commission, Fish \& Wildlife Research Institute to the Gulf and South Atlantic Fisheries Foundation Inc., Tampa, Florida, 73 pp. + 2 CD-ROMs.

Salvador, A. 1987. Late Triassic-Jurassic paleogeography and origin of Gulf of Mexico Basin. American Association of Petroleum Geologists Bulletin. 71: 419-451.

Salvador, A. 1991. Origin and development of the Gulf of Mexico basin. In : Salvador, A., (ed.), The Gulf of Mexico Basin . Geological Society of America : 389-444.

Saucier, R.T. 1994. Geomorphology and Quaternary geologic history of the lower Mississippi valley . Vicksburg, Mississippi. U S Army Engineer Waterways Experiment Station: 364 p.

Schlee, J., 1968, Sand and gravel on the continental shelf off the northeastern United States: U.S. Geological Survey Circular 602, 9 p.

Schlee, John, 1973, Atlantic Continental Shelf and Slope of the United States sediment texture of the northeastern part: U.S. Geological Survey Professional Paper 529-L, 64 p.

Scruton, P.C. 1960. Delta building and the deltaic sequence. In : Shepard, F.P.; Phleger, F.B., and Van Andel, T.H. (eds.). Recent sediments, northwest Gulf of Mexico . American Association of Petroleum Geologists: 82-102.

Shepard, F.P., 1954, Nomenclature based on sand-silt-clay ratios: Journal Sedimentary Petrology, v. 24, p. 151-158.

Stanley, D.J. and Warne, A.G. 1994. Worldwide initiation of Holocene marine deltas by deceleration of sea-level rise. Science. 265: 228-231.

Stone, G.W., Williams, S. J., and Burruss, A., E. 1997. Louisiana's barrier islands: an evaluation of their geological evolution, morphodynamics and rapid deterioration, thematic issue of Journal of Coastal Research on Louisiana's coastal erosion problems. v 13 (3): 591-592.

Suter, J.R. and Berryhill, H.L. Jr. 1985. Late Quaternary shelf-margin deltas, northwest Gulf of Mexico. American Association of Petroleum Geologists Bulletin. 69: 77-91. 
Suter, J.R.; Berryhill, H.L. Jr., and Penland, S. 1987. Late Quaternary sea-level fluctuations and depositional sequences, southwest Louisiana continental shelf. In : Nummedal, D.; Pilkey, O.H., and Howard, J.D. (eds.), Sea-level fluctuation and coastal evolution . Society of Economic Paleontologists and Mineralogists. 41: 199- 219.

Sydow, J. and Roberts, H.H. 1996. Stratigraphic framework of a Late Pleistocene shelf-edge delta, northeast Gulf of Mexico. American Association of Petroleum Geologists. 78(8): 1276-1312.

Tornqvist, T.E., Kidder, T.R., Autin, W.J., van der Borg, K., de Jong, A.F.M., Klerks, C.J.W., Snijers, E.M.A., Storms, J.E.A., van Dam Renkel, L., and Wiemann, M.C. 1996. A revised chronology for Mississippi River subdeltas. Science. 273: 1693-1696.

Wells, J.T. and Kemp, G.P. 1981. Atchafalaya mud stream and recent mudflat progradation: Louisiana Chenier plain. Gulf Coast Association of Geological Societies Transactions . 31: 409416.

Wentworth, C.K., 1922, A scale of grade and class terms for clastic sediments: Journal of Geology, v. 30, p. 377-392.

Wentworth, C.K., 1929, Method of computing mechanical composition of sediments: Geological Society of America Bulletin, v. 40, p. 771-790.

Williams, S.J.; Penland, S., and Circe', R.C. 1989. Distribution and textural character of surficial sediments, Isles Dernieres to Ship Shoal region, Louisiana. Gulf Coast Association of Geological Societies Transactions, 39: 571-576.

Williams, S.J., Penland, S., Sallenger, A.H., Jr., McBride, R.A., and Kindinger, J.L. 1991. Geologic controls on the formation and evolution of Quaternary coastal deposits of the northern Gulf of Mexico, in N.C. Kraus, K.C. Gingrich, and D.L. Kriebel, (eds.), Coastal Sediments '91 . American Society of Civil Engineers, v 1: 1082-1095.

Williams, S.J., Penland, S., and Sallenger, A.H., Jr., (eds.). 1992a. Louisiana Barrier Island Erosion Study Atlas of Shoreline Changes in Louisiana from 1853 to 1989. U.S. Geological Survey Miscellaneous Investigation Series I-2150-A: 107 p.

Williams, S.J., Cichon, H.A., Westphal, K., and Ramsey, K. 1992b. Representative publications from the Louisiana Barrier Island Erosion Study. U.S. Geological Survey Open-File Report 92530: $565 \mathrm{p}$.

Williams, S.J. and Cichon, H.A. 1993. Geologic assessments and characterization of marine sand resources: Gulf of Mexico region: Coastlines of the Gulf of Mexico. Coastal Zone '93 . 8th Symposium on Coastal and Ocean Management: v 1: 217-223.

Williams, S.J., Penland, S., and Roberts, H.H. 1993. Processes affecting coastal wetland loss in the Louisiana deltaic plain: Proceedings, Coastal Zone '93. 8 th Symposium on Coastal and Ocean Management v 1: 211-219.

Williams, S.J., Stone, G.W., and Burruss, A.E. 1997. A perspective on the Louisiana wetland loss and coastal erosion problem. Introduction, thematic issue of Journal of Coastal Research on Louisiana 's coastal erosion problems. v 13 (3): 593-594.

Williams, S.J., Reid, J.M., Cross, V.A. and Polloni, C.F. 2003a, Coastal erosion and wetland change in Louisiana : selected USGS products. U.S.Geological Survey Digital Data Series DDS79. Version 1.0, DVD-ROM.

Williams, S. J., Jenkins, C., Currence, J., Penland, S., Reid, J., Flocks, J., Kindinger, J., Poppe, L., Kulp, M., Manheim, F., Hampton, M., Polloni, C., and Rowland, J. 2003b. "New digital geological maps of U.S. continental margins: insights to sea floor sedimentary character, aggregate resources and processes, Proceedings of the International Conference on Coastal Sediments 2003,: Corpus Christi, Tex., World Scientific Publishing Corporation and East Meets West Productions, Corpus Christi, Tex., 11 p., CD-ROM. 
Williams, S.J., Reid, J., and Manheim, F. 2004. A Bibliography of Selected References to U.S. Marine Sand and Gravel Mineral Resources, U.S. Geological Survey Open-File Report 03-300. ONLINE

Williams, S.J., Kulp, M., Penland, S., Kindinger, J.L., and Flocks, J.G., (in press), Mississippi River Delta Plain, Louisiana Coast and Inner Shelf: Holocene Geologic Framework and Processes, chapter in Gulf of Mexico, its origins, water, biota, and human impacts (C. Holmes and W. Tunnell, eds.), Texas A\&M Press Books.

Wright, L.D. and Colman, J.M., 1973. Variations in morphology of major river deltas as functions of ocean wave and river discharge regimes. American Association of Petroleum Geologists Bulletin. 57: 370-398.

Wright, L.D., 1977. Sediment transport and deposition at river mouths: a synthesis. Geological Society of America Bulletin. 88: 857-868. 


\section{Related Websites}

This report is a product of The USGS Marine Aggregate Resources and Processes Project, and is the second of a series of such publications using usSEABED data to generate example GIS maps directed at promoting a better understanding of sea floor composition, texture, and geologic character.

The U.S. Geological Survey data and products included in this open file report have come from a collection of Federal and state agencies and academic research groups found at the links below.

\section{USGS Links:}

USGS Woods Hole Science Center

USGS Minerals Resources Program

usSEABED Home

USGS Center for Coastal and Watershed Studies

USGS Western Coastal and Marine Geology

USGS Wetlands Research Center

The collaborators listed below have contributed to the usSEABED dataset, and continue to to be involved in the future developments of the project.

\section{Our Collaborators:}

U.S. Army Corps of Engineers

NOAA National Marine Fisheries Service

NOAA National Ocean Service

Minerals Management Service

U.S. Environmental Protection Agency

Louisiana Geological Survey

Texas Bureau of Economic Geology

dbSEABED at INSTAAR/University of Colorado

University of New Orleans

Louisiana Department of Natural Resources

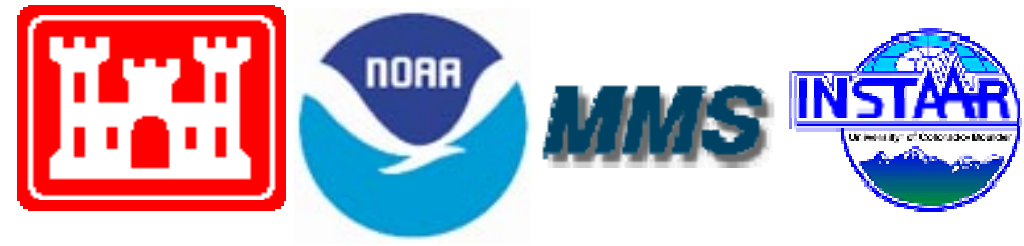

\section{For Educators}

The U.S. Geological Survey provides scientific information intended to help educate the public about natural resources, natural hazards, geospatial data, and issues that affect our quality of 
life. The USGS serves the Nation by providing reliable scientific information to describe and understand the Earth; and enhance and protect our quality of life.

The materials and websites below represent the combined efforts of the USGS and our collaborating institutions to reach the ever growing needs of the public. The products and web links below are to serve as a starting point for educators to see what types of materials are available to assist in lesson planning, public presentations, and increasing the scientific understanding of our dynamic planet.

References: References on marine sand and gravel studies and resources can be found in USGS Open File Report 2003-300 (Williams and others, 2004) and can help provide background information on the geologic framework of continental shelf sediments and processes.

Plotting: Plotting sediment data from the usSEABED program can be done using Matlab routines available on the user contributed code library of the Mathworks website (shepard.m, schlee.m, Folk_S_Classification.m). These scripts were written by members of the Woods Hole Science Center staff to help visualize the compositional components of sediment samples on a ternary diagram.

Movie: New Orleans - THE NATURAL HISTORY - by Walter Williams. Walter Williams has filmed New Orleans on many occasions, including this pre-Hurricane Katrina documentary on the natural forces surrounding New orleans. The movie may also be found in U.S. Geological Survey Digital Data Series 79 (Williams and others, 2003) low resolution version is available on DVD courtesy of Mr. Williams.

\section{Additional Resources Available Online:}

USGS maintains a webpage of Educational Resources, (including A Primer On Natural Aggregate, and Schoolyard Geology).

USGS Coastal and Marine Geology Program provides additional information and educational resources that are available on their website, searchable by the term 'Educational Materials'.

The NOAA Coastal Services Center is an office within the National Oceanic and Atmospheric Administration devoted to serving the nation's state and local coastal resource management programs.

Minerals Management Service maintains a Kids' Pages with excellent materials on a number of scientific topics, including The Ocean's Sand, A Natural Resource (Adobe pdf format)

U.S. Army Corps of Engineers has an Education Center which includes lessons and materials in navigation, sedimentation, and many other topics tied to engineering in the coastal environment.

\section{GIS in Louisiana}

Louisiana Statewide GIS Atlas

Louisiana Dept. of Environmental Quality GIS Center

Louisiana State Land Office GIS Lab 


\section{GIS in Florida}

Florida DEP Geographic Information Systems

Florida Geographic Data Library

Florida GIS Data

\section{GIS in Texas}

Texas Geographic Information Council

Texas Natural Resources Information System

Texas Natural Resource Conservation Commission

East Texas GIS and GPS Users Group

North Central Texas GIS Coordinating Council

Round Rock GIS Data Sets

\section{GIS in Alabama}

Geological Survey of Alabama GIS Group

Alabama Coastal Hazards Assessments GIS

Alabama Land Resource Information Center

Alabama Geographic Alliance

\section{GIS in Mississippi}

Mississippi Automated Resource Mapping System (MARIS)

\section{Acknowledgments}

We thank Larry Poppe (USGS) and Elizabeth Pendleton (USGS) for critically reviewing this report and offering helpful suggestions.

\section{Contacts}

For information about the Marine Aggregate Assessment project and Louisiana delta plain geology:

S. Jeffress Williams, jwilliams@usgs.gov, U.S. Geological Survey, Woods Hole Science Center, 384 Woods Hole Rd, Woods Hole, MA 02543-1598

\section{For Gulf of Mexico data contributions:}

Matthew A. Arsenault, U.S. Geological Survey, Woods Hole Science Center, 384 Woods Hole Rd, Woods Hole, MA 02543-1598, 508-547-8700.

For information about the Pacific Coast Benthic Habitats project:

Jane A. Reid, jareid@usgs.gov, U.S. Geological Survey, Western Coastal and Marine Geology, Pacific Science Center, 400 Natural Bridges Drive, Santa Cruz, CA 95060 


\section{For information or questions regarding the dbSEABED program as well as global data:}

Chris Jenkins, chris.jenkins@ colorado.edu, Institute of Arctic and Alpine Research, University of Colorado at Boulder, 1560 30th Street, Campus Box 450, Boulder, CO 80309-0450

\section{Disclaimer}

\section{General}

This CD-ROM publication was prepared by an agency of the United States Government. Neither the United States Government nor any agency thereof, nor any of their employees, makes any warranty, expressed or implied, or assumes any legal liability or responsibility for the accuracy, completeness, or usefulness of any information, apparatus, product, or process disclosed in this report, or represents that its use would not infringe privately owned rights. Reference herein to any specific commercial product, process, or service by trade name, trademark, manufacturer, or otherwise does not necessarily constitute or imply its endorsement, recommendation, or favoring by the United States Government or any agency thereof. Any views and opinions of authors expressed herein do no necessarily state or reflect those of the United States Government or any agency thereof. Although all data published on this CD-ROM have been used by the USGS, no warranty, expressed or implied, is made by the USGS as to the accuracy of the data and related materials and/or the functioning of the software. The act of distribution shall not constitute any such warranty, and no responsibility is assumed by the USGS in the use of these data, software, or related materials.

\section{Accessibility}

\section{Section 508 and Accessibility at the USGS}

The USGS is committed to and is making every possible effort to ensure that all electronic and information technology developed, procured, maintained, or used by the USGS is accessible to people with disabilities, including both employees and the customers we serve. If you cannot fully access the information on this CD-ROM, please e-mail the contact person or group named in the contact information provided on this CD-ROM, and they will help you. This may include providing the information to you in an alternate format.

For further information and to learn more about the regulations governing the accessibility of Federal electronic information products, visit the Section 508 Web pages listed below:

- Section 508 home page - www.section508.gov/

- Access Board - www.access-board.gov/508.htm

- Web Accessibility Initiative (WAI) - www.w3.org/WAI/

\section{Readme}

\section{Background}

This report contains a compilation of available textural data and numeric data based on lithologic descriptions generated from surficial sediment samples from offshore the Louisiana coast of the United States. These data are a subset of the usSEABED data for the Gulf of Mexico as 
described in Buczkowski and others (2006). More than 340,500 samples containing sediment grain size and lithology have been compiled as part of the U.S. Geological Survey's Marine Aggregate Resources and Processes and National Benthic Habitats projects. These data are being used to update the current maps on surficial sediment distribution for the Louisiana/Ship Shoal region.

Many of these data layers were compiled using gray literature or unpublished sources and have not been available in digital form prior to publication of USGS DS-146. These data have been converted to Environmental Systems Research Institute, Inc. (ESRI) "shapefile" format for use in the project Geographic Information System (GIS), and data are supplied with complete FGDC compliant metadata. Sediment data and sample identifiers are also supplied in flat-file format and Microsoft Excel spreadsheet files for those users who may not have GIS access. 